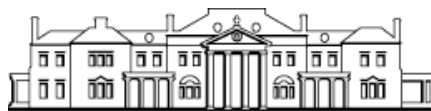

Levy Economics o

Institute

of Bard College

Working Paper No. 885

\title{
Quality of Statistical Match of Household Budget Survey and SILC for Turkey
}

by

Özlem Albayrak

Ankara University

Thomas Masterson

Levy Economics Institute of Bard College

February 2017

The Levy Economics Institute Working Paper Collection presents research in progress by Levy Institute scholars and conference participants. The purpose of the series is to disseminate ideas to and elicit comments from academics and professionals.

Levy Economics Institute of Bard College, founded in 1986, is a nonprofit, nonpartisan, independently funded research organization devoted to public service. Through scholarship and economic research it generates viable, effective public policy responses to important economic problems that profoundly affect the quality of life in the United States and abroad.

Levy Economics Institute

P.O. Box 5000

Annandale-on-Hudson, NY 12504-5000

http://www.levyinstitute.org

Copyright (C) Levy Economics Institute 2017 All rights reserved

ISSN 1547-366X 


\begin{abstract}
This paper presents the quality analysis of the statistical matching conducted for a research study on household consumption behavior, household indebtedness, and inequality for Turkey. The match has been done for four years (2005, 2008, 2009, and 2012) of Household Budget Surveys (HBS) and the Survey on Income and Living Conditions (SILC). The aim of the statistical matching is to transfer household expenditure data from the HBS to the SILC to create synthetic data sets that have information on household consumption expenditures as well as household income and indebtedness. We are following the methodology of constrained statistical matching, using estimated propensity scores developed in Kum and Masterson (2010) to produce the synthetic data sets that we need. The analysis shows that the match is of high quality.
\end{abstract}

Keywords: Statistical Matching; Consumer Economics: Empirical Analysis; Personal Income, Wealth, and Their Distribution; Turkey

JEL Classifications: C14, D12, D31 


\section{INTRODUCTION}

This paper presents the quality analysis for the statistical matching conducted for a research project on household consumption behavior, household indebtedness, and inequality for Turkey. ${ }^{1}$ The matches were done for four years (2005, 2008, 2009, and 2012) of the Household Budget Survey (HBS) and the Survey on Income and Living Conditions (SILC). ${ }^{2}$ The aim of the statistical matching is to transfer household expenditure data from the HBS files to the SILC files. Our particular problem is creating a synthetic micro-data set containing information on both household consumption expenditures (from the HBS) and variables regarding household indebtedness (SILC). Since the 2008 financial crisis, there has been a renewed interest in the causes of household indebtedness and its relation to income distribution. Since the mid-1990s there has been an expansion of household credit all around the world and since the beginning of the 2000s this process has also taken place in Turkey (International Monetary Fund 2006; Lapavitsas 2009). Household saving rates have dropped to record low levels of 12 percent in 2012 from 23 percent at the beginning of the 1990s. In line with this, households have turned to both short- and long-term consumer loans and credit cards. By the end of 2010, all segments of society had increased their consumption level beyond their income levels. There has been very little research on household indebtedness in Turkey (Karacimen 2014, 2016), and none of the existing studies have looked at the relationship between household debt behavior, household consumption patterns, and households' position in the income distribution. Consumption theories based on the relative income hypothesis are increasingly used to explain the dynamics of household indebtedness and changes in consumption patterns in relation to the income distribution in society and so we also want to examine whether the relative income hypothesis can explain household consumption behavior in Turkey in the 2000s.

In order to conduct this analysis, we need a data set containing information on demographic, economic, and social characteristics of individuals and households, particularly debt status, debt amounts, and consumption expenditures of households. In Turkey this information is not available in a single data set, but distributed between two micro-level, nationally representative

\footnotetext{
${ }^{1}$ The research was financially supported by Ankara University and TUBITAK (The Scientific and Technological Research Council of Turkey).

${ }^{2}$ SILC has a panel component, too; however, we used the cross-section data from the SILC.
} 
data sets (HBS and SILC). We create a synthetic data file containing information from the two files with constrained statistical matches (CSM) using propensity score rank (see Kum and Masterson 2010).

The matching algorithm developed by Kum and Masterson (2010: 183) uses "propensity scores to rank observations within prespecified segments and then matches records from the donor data file to records in the recipient data file by rank.” We use Stata programs created at the Levy Economics Institute of Bard College both for estimating propensity scores and the matching procedure. ${ }^{3}$ The rest of this paper is organized as follows. The source data sets are described and their demographic characteristics are compared. Then the quality of the match is reviewed. The marginal and conditional distributions of the transferred variables in the synthetic data set are compared to their distribution in the source data sets.

\section{STATISTICAL MATCHING}

\section{Data and Alignment}

The Turkish Statistical Institute (TurkStat) produces both of the data sets that we use in the matching. The HBS has household consumption expenditure information, in addition to the variables regarding income sources and levels, as well as a variety of demographic information for individuals and households. The SILC contains information on income sources at both the individual and household level, homeownership, mortgage and consumer debt, and-to some extent - the debt servicing burden, which will be critical for studying the dynamics of household indebtedness and consumption behavior. These two data sets have been used separately by researchers so far; however, they have almost never been used together. ${ }^{4}$

The HBS has been conducted annually since $2002,{ }^{5}$ and until the SILC was started in 2005 it was the only micro-level data available for examining issues of income distribution and poverty for

\footnotetext{
${ }^{3}$ Please see Kum and Masterson (2010) for the details.

${ }^{4}$ A very recent paper by Uçar and Betti (2016) transfers household expenditure data from HBS to SILC panel and create a synthetic longitudinal data set.

${ }^{5}$ Though the HBS was introduced in 1994, it only became a regularly conducted, reliable data set after 2002.
} 
Turkey. In the efforts to have micro-level data consistent with that available in EU countries, TurkStat began the SILC project and now uses it to produce estimates of official income distribution and poverty statistics, arguing that the income data in the SILC is better than that in the HBS. The SILC has panel data available in addition to the cross-sectional annual data we use. Except for 2003, the HBS allows only a rural/urban geographic breakdown, whereas SILC can be disaggregated into 12 regions, which is critically important in order to examine the consumption behavior of households based on the relative income hypothesis. Although the sample size has become smaller and the number of variables about income sources has been reduced in the years since the inception of the SILC, the HBS is still the only micro-level data set available that has both household expenditure and income variables. The latest year of data available for the HBS is 2013; however, since the SILC for 2013 had not yet been made available for public use when we started our research, we used 2012 as the final year of our analysis. As the first year available in the SILC is 2005, the starting point of our analysis is 2005.

We examine four benchmark years (2005, 2008, 2009, and 2012) to analyze changes in household debt. Although the credit expansion and the phenomena of household indebtedness had started around 2003 in Turkey (after the recovery from the 2001 crisis), our work will treat 2005 as the base year since it is the earliest year that we have data for. Table 1 shows the main features of the data sets for each of the years in our study. The sample size of the SILC is somewhat larger than that of the HBS, especially in 2012. Due in part to the larger sample size, SILC is regionally representative. Unfortunately, since (except for 2003) the HBS has only the rural/urban breakdown, we are not able to use regional disaggregation in the matching procedure.

Another point we should make is that in 2007, TurkStat changed the way that it estimates the national population (it switched to an address-based population record system), which is critical in determining the sampling weights for representative surveys. As the HBS used projections of the population estimations from 2000 until 2007 and SILC used this new system from its beginning, there is a large difference in their estimates of national population (four million people). As we will see below, this also causes larger differences in the distribution of strata variables between the two surveys for this year. 


\section{Alignment for Reference Periods of the Surveys}

All of the variables in both data sets refer to the survey period ( $\mathrm{t}$ ) with two exceptions. The income variables in the SILC refer to net individual and household income earned in the year prior to the survey (t-1), while the HBS reports incomes earned in the survey period. In order to overcome this problem, we prefer to match $\operatorname{HBS}(\mathrm{t}-1)$ to $\operatorname{SILC}(\mathrm{t}){ }^{6}{ }^{6}$ As for the age of the individuals, the variable in the HBS corresponds to the age at the time of the survey, while in the SILC, age is defined as the age at the end of the income reference period. Therefore, since we match SILC(t) with HBS(t-1), we do not have any inconsistency with regard for age. By matching SILC(t) with HBS(t-1) we solve the problem with income; however the rest of the common variables we use in the matching procedure will have different reference periods. A comparison of the strata variables for SILC(t), HBS(t), and HBS(t-1) indicates that the distribution of common variables other than income exhibit very similar patterns (tables 2 and 5). Therefore, we have reasonable confidence in our solution for dealing with data reference periods in the two surveys.

\section{Common Variables}

The first step of the statistical matching procedure is the determination of the common variables in the two data sets, as well as the selection of which variables to use as strata variables (used to partition the data into matching cells) and as matching variables (used to estimate propensity scores within the matching cells). The variables common to the SILC and HBS are region (rural/urban), household disposable income ranges, educational attainment category of the household head, age category of the household head, family type, a dummy variable indicating if the household head is actively in employment, the sex of the household head, homeownership status, the marital status of the household head, the employment type of the household head (casual or permanent), the industry in which the household head works, a dummy variable indicating if the spouse of the household head has any income, household per capita disposable income, the number of kids, the household size, the existence of an unemployed individual in the household, a dummy variable indicating the existence of wage income in the household, and the number of the rooms in the household's residence.

\footnotetext{
${ }^{6}$ Uçar and Betti (2016) did not use this solution, since common variables other than age would not be consistent. Since they could follow the same individuals and households for four years, they relate each year's SILC data with the following year's income. Their method matches $\operatorname{HBS}(t)$ to SILC( $(t)$ with the income variables from SILC( $t+1)$.
} 
In order to transfer consumption expenditure as closely as possible, we used the following strata variables in the match: household disposable income ranges, rural/urban status, the educational attainment category of the household head, the age category of the household head, the family type, and a dummy variable indicating if the household head is employed. These variables are chosen due to their close relationship to household debt and consumption expenditures. The literature on household indebtedness also suggests that the income level of the household and the age, level of education, and employment status of the household head are the main variables affecting household indebtedness (Magri, Pico, and Rampazzi 2011; Adalid, Lojschová, and Westermann 2011). These variables can also be expected to determine the consumption patterns of households. ${ }^{7}$

We want to transfer household expenditure data from the HBS to SILC. Monthly household expenditure data in the HBS is very detailed at the household level. Expenditures in the HBS are classified using the United Nations’ five-digit Classification of Individual Consumption According to Purpose (COICOP) classifications. In preparation for the matching procedure, we created 21 expenditure categories, ${ }^{8}$ such as food, clothing, housing, rent, durables, nondurables, education, health, and so on and transferred amounts for these expenditure categories along with total household expenditures in the matching procedure.

The next step of the matching process is aligning the common variables in the two files. The common variables should be defined in the same way and distributed similarly in order to ensure a good quality match. For example, variables providing information on the working life and employment type of individuals frequently differ in the two data sets. While one variable indicating whether an individual is an employer, an employee, or an unpaid family worker is the same for both data sets (named ISDUR in the HBS and FI120 in the SILC), other variables regarding the employment status of individuals differ (there are two different variables in SILC: FI010 and FK210). In order to determine if individuals are currently working, retired, students,

\footnotetext{
${ }^{7}$ Sutherland, Taylor, and Gomulka (2002) combine expenditure and income data for the UK. The common variables for the matching procedure are similar to ours.

${ }^{8}$ The aggregate expenditure categories we created are: food, alcohol and tobacco, clothing, rent, housing (expenses on residences including rent and imputed rent), utilities, durables, nondurables, phone, cars, utilities, repair services, transportation, personal care and recreational services, education, health (two groups: services and goods), insurance, and other services and goods.
} 
or unemployed, we use nine different variables across the two data sets. ${ }^{9}$ Moreover, TurkStat has frequently changed how they collect some of the characteristics of individuals, such as age, marital status, and employment status (particularly in the HBS); hence, we make the strata and matching variables in the two data sets as consistent as possible by creating new variables with the same definition for each data set. Age is collected as a categorical variable in 2009 for HBS, and in 2005 and 2012 for SILC. We therefore created a new categorical variable for age with a consistent definition for all years and both data sets. Finally, the family type variable is defined differently in the two data sets. We prefer to use the HBS definition, so we created a new family type variable for SILC that is consistent with the HBS definition.

In tables 2 through 5, we compare the distributions of strata variables in the two data sets for each study year. As mentioned above, the 2005 sampling weights of the two surveys were estimated using different population projections. Hence, there are large differences in the distribution of rural and urban households between the HBS and the SILC. Although the magnitude of this inconsistency can also be seen in the age and family type variables for 2005, we do not observe the same problem for the other study years. The largest difference in the distribution of strata variables is for the dummy of the employment status of the household head. As mentioned above, the reason behind this difference might be that we use four different variables to create this dummy.

In table 6, we compare the weighted frequencies between surveys by a combination of strata variables: household disposable income ranges, the education level of the household head, and rural/urban status for 2012. There are differences between the surveys, however these differences are reasonable for most cells except the cells defined with the highest income range and higher education. The reason for these differences is that the number of records in these categories is very limited in both surveys.

\footnotetext{
${ }^{9}$ ISDUR, ISNEDEN, CALIS_AY, and IS_ARAMA in the HBS and FI010, FI020, FI040, FI120, and FK210 in the SILC. By using these variables we created a common variable in both data sets categorizing the household head as an employer, an employee, an unpaid family worker, a student, retired, or inactive for reasons other than being a student or retired. We used this variable to estimate propensity scores, but we created one more variable out of this with only two categories (active and inactive) as a strata variable (a dummy for active household heads).
} 


\section{Quality Assessment}

Tables 7 through 10 give the frequencies of matched households by the years examined. We combined our six strata variables, yielding a maximum possible number of 965 matching cells in the first round for each match. However, many of these cells either had no donor records, no recipient records, or an inadequate total number of records for the propensity score estimation. Thus we could not estimate propensity scores for these cells, which reduced the number of matches in the first rounds of each study year. Nonetheless, we were able to match 90 percent of the weighted records in first three to five rounds for each year. Figure 1 through 4 provide comparisons of the distribution of total household expenditures in the donor and matched data sets. The first two figures display the differences in the Lorenz curves of household expenditures for 2005 and 2012. The differences between Lorenz curves are reasonably small (less than 0.0025 percent for all percentiles) for both years, and for the first 40 percent of the distributions for 2012 there is no measurable difference. The comparisons of the density functions for expenditures also show a good transfer of the overall distribution (figures 3 and 4).

In order to have a more complete picture of the match quality, we move on to compare the conditional distributions in the donor and matched data sets. Tables 11 through 14 present the comparison of mean and median values of total household expenditure and chosen expenditure groups between the donor file and the matched file for each year. Mean values are almost exactly matched except for education expenditures for 2005, while clothing expenditures have the highest deviation of the median values.

Examination of the quality of the match within population subgroups shows generally good results. Figure 5 through 12 display ratios of mean and median household expenditure for all years between the matched file and the HBS for the categories of all six strata variables. We have the greatest deviation within the highest (2009) and the lowest income ranges (2012) and for household heads aged 65 and above (2005 and 2012).

We also compare the mean values of the transferred variables by income deciles in the matched file to those in the donor file, as the distributional aspect of expenditures and indebtedness is an important part of our research. Tables 16 to 23 present the mean values of some transferred 
expenditure categories by deciles of per capita household disposable income. ${ }^{10}$ But before that it would be helpful to see how well the mean values of ranking variables are aligned in the two data sets. Table 15 gives mean values of per capita household income by deciles. The differences between mean values of per capita income are generally higher for the bottom and top of the distributions. These differences are reflected in the differences of the distributions of expenditure categories. The highest differences between means come from the distribution of expenditures on housing (including rent). The ratio between the matched and donor data sets drops to 73 percent for the poorest decile in 2005 for this expenditure category.

Finally, Gini coefficients for per capita total household expenditure and disposable incomes for both data sets for each year are given in tables 24 and 25. The Gini coefficients of household total expenditures are virtually the same for all years except for 2008. For 2008, the difference between the matched data set and the original HBS file is still very reasonable at less than 2 points.

Overall, the quality of the match is very good. The overall distribution is transferred almost perfectly, and the distributions within subgroups are transferred with good precision except for some subgroups, such as the lowest and highest income groups for some years and subgroups with small numbers of observations. With the help of figures 5 through 12, which present the ratios of mean and median values of total household expenditure between the synthetic data sets and HBS data by strata variables, we look at each year closely to explain the differences by subgroups. The precision of the matching drops for the family type variable in 2005. The second (couples without kids) and fourth categories (single parent and unrelated members) for this strata

\footnotetext{
${ }^{10}$ The disposable household income definitions in the HBS and the SILC are very similar. However there are some differences regarding the definition of the income variables in the two data sets that may potentially cause differences in measured income in the two data sets, in addition to the different period of time that households are interviewed in two data sets (HBS is conducted in the same year for which the estimations are produced; on the other hand, SILC is conducted in the year after). SILC collects information about the property taxes and other taxes (other than income and indirect taxes) that households pay and deducts the total from household income to arrive at disposable household income. HBS asks each individual their annual income net of income and payroll taxes and investment expenditures and uses this as disposable income. Secondly, the number of income questions is not the same in the two data sets. While SILC has more questions for social transfers, HBS has more questions about interest income, for example. Another problem is that the questionnaire of the HBS has been changed several times since 2005 and the number of income questions has decreased. This, combined with the fact that the SILC is now used as the main income data source, raises questions about the consistency and quality of the HBS for income measurement, at least for later years.
} 
variable have the lowest population shares in both data sets (13 and 12 percent, respectively, in SILC and 13.5 and 8.5 percent in HBS). In addition to this, as shown in table 2, the fourth category is the most unbalanced between the SILC and HBS, leading to the relatively lower precision of the transfer. The 2008 match suffers from the same problems. For 2012, the strata variable for income groups has the lowest precision of the transfer. The lowest and highest income categories have the smallest population shares (15 percent and 8 percent, respectively) and also the smallest numbers of observations. As mentioned earlier, the income variables in the HBS have gone through a number of changes since 2005 and the quality of the income variable has been thought to have decreased because of these changes.

Finally, figures 13 and 14 present the ratios of mean and median values of total household expenditures between the synthetic data sets and HBS data by combinations of the rural/urban breakdown, income categories, and age groups for 2005 and 2012. The figures confirm the quality of the match in general. The precision of the transfer decreases to very low ratios only for the subcells with very few records, particularly for the lowest and highest income groups and the youngest and oldest age groups, as expected. 


\section{REFERENCES}

Adalid, Ramón, Adriana Lojschová, and Thomas Westermann. 2011. "Household Sector Borrowing in the Euro Area - a Micro Data Perspective.” Occasional Paper Series 125. Frankfurt: European Central Bank. Available at: http://econpapers.repec.org/paper/ecbecbops/20110125.htm.

International Monetary Fund. 2006. "Household Credit Growth in Emerging Market Countries.” Global Financial Stability Report: Market Development and Issues. Washington, DC: International Monetary Fund.

Karacimen, Elif. 2014. "Financialization in Turkey: The Case of Consumer Debt.” Journal of Balkan and Near Eastern Studies 16(2): 161-80. doi:10.1080/19448953.2014.910393.

- 2016. "Consumer Credit as an Aspect of Everyday Life of Workers in Developing Countries: Evidence from Turkey.” Review of Radical Political Economics 48(2): 252-68. doi:10.1177/0486613415591806.

Kum, Hyunsub, and Thomas Neal Masterson. 2010. "Statistical Matching Using Propensity Scores: Theory and Application to the Analysis of the Distribution of Income and Wealth.” Journal of Economic and Social Measurement 35(3-4): 177-96. doi:10.3233/JEM-2010-0332.

Lapavitsas, Costas. 2009. "Financialised Capitalism: Crisis and Financial Expropriation.” Historical Materialism 17(2): 114-48. doi:10.1163/156920609X436153.

Magri, Silvia, Raffaella Pico, and Cristiana Rampazzi. 2011. "Which Households Use Consumer Credit in Europe?” Questioni di Economia e Finanza (Occasional Papers) 100. Rome: Bank of Italy, Economic Research and International Relations Area. Available at: https://ideas.repec.org/p/bdi/opques/qef_100_11.html.

Sutherland, Holly, Rebecca Taylor, and Joanna Gomulka. 2002. "Combining Household Income and Expenditure Data in Policy Simulations.” The Review of Income and Wealth 48(4): 517-36. doi:10.1111/1475-4991.00066.

Uçar, Baris, and Gianni Betti. 2016. "Longitudinal Statistical Matching: Transferring Consumption Expenditure from HBS to SILC Panel Survey.” Papers of the Department, No. 739. Siena: Department of Economics, University of Siena. Available at: http://econpapers.repec.org/paper/usiwpaper/739.htm. 
Table 1: Sampling Size of Surveys (1000)

\begin{tabular}{|l|c|c|c|c|c|c|c|c|}
\hline & \multicolumn{2}{|c|}{2005} & \multicolumn{2}{c|}{2008} & \multicolumn{2}{c|}{2009} & \multicolumn{2}{c|}{2012} \\
\hline Surveys & SILC(06) & HBS(05) & SILC(09) & HBS(08) & SILC(10) & HBS(09) & SILC(13) & HBS(12) \\
\hline $\begin{array}{l}\text { Number of } \\
\text { Individuals }\end{array}$ & 42.8 & 35.5 & 45.4 & 33.3 & 45.4 & 38.5 & 73.5 & 36.3 \\
\hline Population & 67,600 & 71,600 & 70,500 & 69,700 & 71,300 & 70,500 & 74,500 & 74,500 \\
\hline $\begin{array}{l}\text { Number of } \\
\text { Households }\end{array}$ & 10.9 & 8.6 & 11.9 & 8.5 & 12.1 & 10.0 & 19.9 & 10.0 \\
\hline $\begin{array}{l}\text { Weighted } \\
\text { Number of } \\
\text { Households }\end{array}$ & 17,300 & 17,500 & 19,200 & 17,800 & 19,300 & 18,400 & 20,600 & 20,100 \\
\hline
\end{tabular}


Table 2: Comparison of Strata Variables for 2005 Match

\begin{tabular}{|c|c|c|c|c|}
\hline HH Income Ranges & SILC 2006 (\%) & $\begin{array}{l}\text { HBS } 2005 \\
(\%)\end{array}$ & Difference & HBS 2006 (\%) \\
\hline$<=6000$ & 18.17 & 17.15 & 1.02 & \\
\hline $6,000-12,000$ & 34.85 & 35.58 & -0.73 & \\
\hline $12,000-24,000$ & 32.41 & 34.15 & -1.74 & \\
\hline $24,000-36,000$ & 8.85 & 8.88 & -0.03 & \\
\hline $36,000-60,000$ & 4.03 & 3.06 & 0.97 & \\
\hline$>60000$ & 1.69 & 1.18 & 0.51 & \\
\hline Family Type & SILC 2006 (\%) & $\begin{array}{l}\text { HBS } 2005 \\
(\%)\end{array}$ & Difference & HBS 2006 (\%) \\
\hline $\begin{array}{r}\begin{array}{r}\text { Nuclear family with } \\
\text { kids }\end{array} \\
\end{array}$ & 56.9 & 58.63 & -1.73 & 60.7 \\
\hline Couple without kids & 13 & 14 & -0.5 & 12.96 \\
\hline Traditional family & 18.02 & 19.33 & -1.31 & 19.17 \\
\hline $\begin{array}{r}\text { Single parent/ } \\
\text { unrelated members }\end{array}$ & 12.01 & 8.47 & 3.54 & 7.17 \\
\hline $\begin{array}{l}\text { Educational Level of } \\
\text { Reference Individual }\end{array}$ & SILC 2006 (\%) & $\begin{array}{l}\text { HBS } 2005 \\
\quad(\%)\end{array}$ & Difference & HBS 2006 (\%) \\
\hline $\begin{array}{r}\text { Primary/illiterate/ } \\
\text { literate without school }\end{array}$ & 63.68 & 64.39 & -0.71 & 64.62 \\
\hline Secondary & 10.14 & 10.59 & -0.45 & 10.96 \\
\hline High school & 15.77 & 16.19 & -0.42 & 15.72 \\
\hline Higher education & 10.41 & 8.84 & 1.57 & 8.7 \\
\hline $\begin{array}{l}\text { Age of Reference } \\
\text { Individual }\end{array}$ & SILC 2006 (\%) & $\begin{array}{l}\text { HBS } 2005 \\
\quad(\%)\end{array}$ & Difference & HBS 2006 (\%) \\
\hline $15-29$ & 10.72 & 7.52 & 3.2 & 7.95 \\
\hline $30-44$ & 39.91 & 38.14 & 1.77 & 39.94 \\
\hline $45-64$ & 35.57 & 40.82 & -5.25 & 40.03 \\
\hline $65+$ & 13.8 & 13.52 & 0.28 & 12.08 \\
\hline $\begin{array}{l}\text { Employment Status of } \\
\text { Reference Individual }\end{array}$ & SILC 2006 (\%) & $\begin{array}{l}\text { HBS } 2005 \\
\quad(\%)\end{array}$ & Difference & HBS 2006 (\%) \\
\hline Active & 65.84 & 69.8 & -3.96 & 70.99 \\
\hline Inactive & 34.16 & 30.2 & 3.96 & 29.01 \\
\hline Region & SILC 2006 (\%) & $\begin{array}{l}\text { HBS } 2005 \\
(\%)\end{array}$ & Difference & HBS 2006 (\%) \\
\hline Rural & 27.22 & 35.56 & -8.34 & 35.56 \\
\hline Urban & 72.78 & 64.44 & 8.34 & 64.44 \\
\hline
\end{tabular}


Table 3: Comparison of Strata Variables for 2008 Match

\begin{tabular}{|c|c|c|c|}
\hline HH Income Ranges & SILC 2009 (\%) & HBS 2008 (\%) & Difference \\
\hline$<=12,000$ & 33.12 & 31.51 & 1.61 \\
\hline $12,000-24,000$ & 39.3 & 40.12 & -0.82 \\
\hline $24,000-36,000$ & 15.32 & 16.46 & -1.14 \\
\hline $36,000-60,000$ & 9.01 & 8.83 & 0.18 \\
\hline $60,000+$ & 3.25 & 3.08 & 0.17 \\
\hline Family Type & SILC 2009 (\%) & HBS 2008 (\%) & Difference \\
\hline Nuclear family with kids & 53.68 & 57.42 & -3.74 \\
\hline Couple without kids & 16.09 & 13.48 & 2.61 \\
\hline Traditional family & 16.25 & 20.34 & -4.09 \\
\hline Single parent/unrelated members & 13.98 & 8.76 & 5.22 \\
\hline $\begin{array}{l}\text { Educational Level of Reference } \\
\text { Individual }\end{array}$ & SILC $2009(\%)$ & HBS $2008(\%)$ & Difference \\
\hline Up to primary & 60.9 & 57.35 & 3.55 \\
\hline Secondary & 10.34 & 11.32 & -0.98 \\
\hline High school & 17.2 & 19.05 & -1.85 \\
\hline Higher education & 11.56 & 12.28 & -0.72 \\
\hline Age of Reference Individual & SILC $2009(\%)$ & HBS 2008 (\%) & Difference \\
\hline 15-29 & 9.25 & 8.95 & 0.3 \\
\hline $30-44$ & 37.49 & 38.99 & -1.5 \\
\hline $45-64$ & 38.06 & 38.29 & -0.23 \\
\hline $65+$ & 15.21 & 13.76 & 1.45 \\
\hline $\begin{array}{l}\text { Employment Status of Reference } \\
\text { Individual }\end{array}$ & SILC 2009 (\%) & HBS $2008(\%)$ & Difference \\
\hline Active & 62.97 & 69.15 & -6.18 \\
\hline Inactive & 37.03 & 30.85 & 6.18 \\
\hline Region & SILC 2009 (\%) & HBS 2008 (\%) & Difference \\
\hline Rural & 29.2 & 29.19 & 0.01 \\
\hline Urban & 70.8 & 70.81 & -0.01 \\
\hline
\end{tabular}


Table 4: Comparison of Strata Variables for 2009 Match

\begin{tabular}{|c|c|c|c|}
\hline HH Income Ranges & SILC $2010(\%)$ & HBS 2009 (\%) & Difference \\
\hline$<=12,000$ & 29.05 & 29.26 & -0.21 \\
\hline $12,000-24,000$ & 41.43 & 39.59 & 1.84 \\
\hline $24,000-36,000$ & 16.97 & 18.02 & -1.05 \\
\hline $36,000-60,000$ & 8.93 & 9.66 & -0.73 \\
\hline $60,000+$ & 3.61 & 3.47 & 0.14 \\
\hline Family Type & SILC 2010 (\%) & HBS 2009 (\%) & Difference \\
\hline Nuclear family with kids & 54.68 & 54.95 & -0.27 \\
\hline Couple without kids & 15.45 & 14.12 & 1.33 \\
\hline Traditional family & 16.26 & 18.43 & -2.17 \\
\hline $\begin{array}{r}\text { Single parent/unrelated } \\
\text { members }\end{array}$ & 13.62 & 12.5 & 1.12 \\
\hline $\begin{array}{l}\text { Educational Level of } \\
\text { Reference Individual }\end{array}$ & SILC 2010 (\%) & HBS 2009 (\%) & Difference \\
\hline Up to primary school & 60.08 & 61.38 & -1.30 \\
\hline Secondary & 10.31 & 10.5 & -0.19 \\
\hline High school & 8.46 & 8.61 & -0.15 \\
\hline Higher education & 21.15 & 19.5 & 1.65 \\
\hline $\begin{array}{l}\text { Age of Reference } \\
\text { Individual }\end{array}$ & SILC 2010 (\%) & HBS 2009 (\%) & Difference \\
\hline 15-29 & 9.59 & 9.34 & 0.25 \\
\hline $30-44$ & 37.48 & 38.08 & -0.60 \\
\hline $45-64$ & 38.04 & 38.01 & 0.03 \\
\hline $65+$ & 14.9 & 14.57 & 0.33 \\
\hline $\begin{array}{l}\text { Employment Status of } \\
\text { Reference Individual }\end{array}$ & SILC 2010 (\%) & HBS 2009 (\%) & Difference \\
\hline Active & 64.88 & 69.07 & -4.19 \\
\hline Inactive & 35.12 & 30.94 & 4.18 \\
\hline Region & SILC $2010(\%)$ & HBS 2009 (\%) & Difference \\
\hline Rural & 29.26 & 28.64 & 0.62 \\
\hline Urban & 70.74 & 71.36 & -0.62 \\
\hline
\end{tabular}


Table 5: Comparison of Strata Variables for 2012 Match

\begin{tabular}{|c|c|c|c|c|}
\hline HH Income Ranges & SILC $2013(\%)$ & HBS $2012(\%)$ & Difference & HBS $2013(\%)$ \\
\hline$<=12,000$ & 15.14 & 13.69 & 1.45 & \\
\hline $12,000-24,000$ & 38.41 & 36.35 & 2.06 & \\
\hline $24,000-36,000$ & 22.64 & 24.34 & -1.7 & \\
\hline $36,000-60,000$ & 15.79 & 17.95 & -2.16 & \\
\hline $60,000+$ & 8.01 & 7.67 & 0.34 & \\
\hline Family Type & SILC $2013(\%)$ & HBS $2012(\%)$ & Difference & HBS $2013(\%)$ \\
\hline Nuclear family with kids & 53.56 & 54.33 & -0.77 & 54.05 \\
\hline Couple without kids & 16.24 & 15.31 & 0.93 & 16.33 \\
\hline Traditional family & 15.1 & 15.1 & 0.00 & 14.49 \\
\hline $\begin{array}{r}\text { Single parent/unrelated } \\
\text { members }\end{array}$ & 15.1 & 15.25 & -0.15 & 15.13 \\
\hline $\begin{array}{l}\text { Educational Level of } \\
\text { Reference Individual }\end{array}$ & SILC $2013(\%)$ & HBS 2012 (\%) & Difference & HBS $2013(\%)$ \\
\hline Up to primary school & 58.07 & 55.99 & 2.08 & 54.78 \\
\hline Secondary & 10.91 & 11.17 & -0.26 & 12.3 \\
\hline High school & 16.5 & 17.67 & -1.17 & 17.44 \\
\hline Higher education & 14.52 & 15.16 & -0.64 & 15.48 \\
\hline $\begin{array}{l}\text { Age of Reference } \\
\text { Individual }\end{array}$ & SILC 2013 (\%) & HBS 2012 (\%) & Difference & HBS 2013 (\%) \\
\hline 15-29 & 8.16 & 8.41 & -0.25 & 8.26 \\
\hline $30-44$ & 36.14 & 37.78 & -1.64 & 37.6 \\
\hline $45-64$ & 39.89 & 39.29 & 0.6 & 39.89 \\
\hline $65+$ & 15.81 & 14.51 & 1.3 & 14.25 \\
\hline $\begin{array}{l}\text { Employment Status of } \\
\text { Reference Individual }\end{array}$ & SILC $2013(\%)$ & HBS 2012 (\%) & Difference & HBS 2013 (\%) \\
\hline Active & 65.68 & 70.86 & -5.18 & 70.38 \\
\hline Inactive & 34.32 & 29.14 & 5.18 & 29.62 \\
\hline Region & SILC $2013(\%)$ & HBS $2012(\%)$ & Difference & HBS $2013(\%)$ \\
\hline Rural & 30.04 & 30.69 & -0.65 & 29.71 \\
\hline Urban & 69.96 & 69.31 & 0.65 & 70.29 \\
\hline
\end{tabular}


Table 6: Comparison of SILC and HBS in Weighted Frequency by Cell

\begin{tabular}{|c|c|c|c|c|}
\hline & \multicolumn{2}{|c|}{ HBS (2012) } & \multicolumn{2}{|c|}{ SILC (2013) } \\
\hline & Rural & Urban & Rural & Urban \\
\hline \multicolumn{5}{|l|}{ Up to primary } \\
\hline$<=12,000$ & $1,485,796$ & 893,572 & $1,527,025.42$ & $1,008,330$ \\
\hline $12,000-24,000$ & $1,916,392$ & $2,935,720$ & $2,107,016$ & $3,193,948$ \\
\hline $24,000-36,000$ & 769,881 & $1,726,231$ & 743,589 & $1,682,217$ \\
\hline $36,000-60,000$ & 320,716 & 993,933 & 377,884 & 968,693 \\
\hline $60,000+$ & 103,554 & 212,842 & 95,904 & 274,633 \\
\hline \multicolumn{5}{|l|}{ Secondary } \\
\hline$<=12,000$ & 95,304 & 107,428 & 90,434 & 176,635 \\
\hline $12,000-24,000$ & 342,391 & 733,387 & 232,888 & 785,162 \\
\hline $24,000-36,000$ & 151,422 & 525,204 & 124,249 & 474,784 \\
\hline $36,000-60,000$ & 44,782 & 310,663 & 51,062 & 223,245 \\
\hline $60,000+$ & 26,554 & 56,828 & 13,581 & 78,853 \\
\hline \multicolumn{5}{|l|}{ High school } \\
\hline$<=12,000$ & 72,673 & 126,640 & 88,283 & 170,020 \\
\hline $12,000-24,000$ & 247,771 & 960,911 & 186,643 & $1,056,572$ \\
\hline $24,000-36,000$ & 197,759 & 930,036 & 127,506 & 813,504 \\
\hline $36,000-60,000$ & 97,031 & 773,644 & 75,293 & 612,263 \\
\hline $60,000+$ & 42,370 & 265,220 & 30,866 & 242,473 \\
\hline \multicolumn{5}{|l|}{ Higher education } \\
\hline$<=12,000$ & 9,806 & 22,944 & 13,476 & 49,840 \\
\hline $12,000-24,000$ & 50,989 & 285,761 & 57,403 & 304,343 \\
\hline $24,000-36,000$ & 137,429 & 565,243 & 108,950 & 594,818 \\
\hline $36,000-60,000$ & 131,038 & $1,011,637$ & 93,568 & 856,306 \\
\hline $60,000+$ & 62,397 & 806,345 & 50,347 & 865,104 \\
\hline
\end{tabular}


Table 7: Distribution of Matched Records by Matching Round, 2005

\begin{tabular}{|c|c|c|c|}
\hline Rounds & $\begin{array}{c}\text { Matched } \\
\text { Households }\end{array}$ & Percent of Total & $\begin{array}{c}\text { Cumulative } \\
\text { Percentage }\end{array}$ \\
\hline $\mathbf{1}$ & $10,093,054$ & 58.39 & 58.39 \\
\hline $\mathbf{2}$ & $2,081,540$ & 12.04 & 70.44 \\
\hline $\mathbf{3}$ & $1,993,323$ & 11.53 & 81.97 \\
\hline $\mathbf{4}$ & $1,184,206$ & 6.85 & 88.82 \\
\hline $\mathbf{5}$ & 575,908 & 3.33 & 92.15 \\
\hline $\mathbf{6}$ & 307,696 & 1.78 & 93.93 \\
\hline $\mathbf{7}$ & 289,368 & 1.67 & 95.61 \\
\hline $\mathbf{8}$ & 267,634 & 1.55 & 97.16 \\
\hline $\mathbf{9}$ & 67,950 & 0.39 & 97.55 \\
\hline $\mathbf{1 0}$ & 62,100 & 0.36 & 97.91 \\
\hline $\mathbf{1 1}$ & 45,873 & 0.27 & 98.17 \\
\hline $\mathbf{1 2}$ & 49,829 & 0.29 & 98.46 \\
\hline $\mathbf{1 3}$ & 21,890 & 0.13 & 98.59 \\
\hline $\mathbf{1 4}$ & 10,462 & 0.06 & 98.65 \\
\hline $\mathbf{1 5}$ & 32,135 & 0.19 & 98.84 \\
\hline $\mathbf{1 6}$ & 5,061 & 0.03 & 98.94 \\
\hline $\mathbf{1 7}$ & 12,687 & 0.07 & 99.97 \\
\hline $\mathbf{1 8}$ & 178,446 & 1.03 & 100 \\
\hline $\mathbf{1 9}$ & 5,003 & 0.03 & \\
\hline Total & $17,284,165$ & 100 & \\
\hline
\end{tabular}


Table 8: Distribution of Matched Records by Matching Round, 2008

\begin{tabular}{|c|c|c|c|}
\hline Rounds & $\begin{array}{c}\text { Matched } \\
\text { Households }\end{array}$ & Percent of Total & $\begin{array}{c}\text { Cumulative } \\
\text { Percentage }\end{array}$ \\
\hline $\mathbf{1}$ & $11,481,257$ & 59.77 & 59.77 \\
\hline $\mathbf{2}$ & $1,809,189$ & 9.42 & 69.19 \\
\hline $\mathbf{3}$ & $2,204,363$ & 11.48 & 80.67 \\
\hline $\mathbf{4}$ & $1,728,318$ & 9 & 89.67 \\
\hline $\mathbf{5}$ & 528,431 & 2.75 & 92.42 \\
\hline $\mathbf{6}$ & 360,306 & 1.88 & 94.29 \\
\hline $\mathbf{7}$ & 300,486 & 1.56 & 95.86 \\
\hline $\mathbf{8}$ & 411,266 & 2.14 & 98 \\
\hline $\mathbf{9}$ & 49,930 & 0.26 & 98.26 \\
\hline $\mathbf{1 0}$ & 68,523 & 0.36 & 98.62 \\
\hline $\mathbf{1 1}$ & 50,245 & 0.26 & 98.88 \\
\hline $\mathbf{1 2}$ & 119,543 & 0.62 & 99.5 \\
\hline $\mathbf{1 3}$ & 20,168 & 0.1 & 99.61 \\
\hline $\mathbf{1 4}$ & 46,888 & 0.24 & 99.85 \\
\hline $\mathbf{1 5}$ & 9,741 & 0.05 & 99.9 \\
\hline $\mathbf{1 6}$ & 9,893 & 0.05 & 99.95 \\
\hline $\mathbf{1 7}$ & 884 & 0 & 99.96 \\
\hline $\mathbf{1 8}$ & 4,231 & 0.02 & 99.98 \\
\hline $\mathbf{1 9}$ & 1,575 & 0.01 & 99.99 \\
\hline $\mathbf{2 0}$ & 2,626 & 0.01 & 100 \\
\hline Total & $19,207,863$ & 100 & \\
\hline & & & \\
\hline
\end{tabular}


Table 9: Distribution of Matched Records by Matching Round, 2009

\begin{tabular}{|c|c|c|c|}
\hline Rounds & $\begin{array}{c}\text { Matched } \\
\text { Households }\end{array}$ & Percent of Total & $\begin{array}{c}\text { Cumulative } \\
\text { Percentage }\end{array}$ \\
\hline $\mathbf{1}$ & $12,298,755$ & 63.65 & 63.65 \\
\hline $\mathbf{2}$ & $2,016,500$ & 10.44 & 74.09 \\
\hline $\mathbf{3}$ & $2,053,602$ & 10.63 & 84.72 \\
\hline $\mathbf{4}$ & $1,141,590$ & 5.91 & 90.63 \\
\hline $\mathbf{5}$ & 584,618 & 3.03 & 93.65 \\
\hline $\mathbf{6}$ & 447,466 & 2.32 & 95.97 \\
\hline $\mathbf{7}$ & 183,899 & 0.95 & 96.92 \\
\hline $\mathbf{8}$ & 185,352 & 0.96 & 97.88 \\
\hline $\mathbf{9}$ & 91,869 & 0.48 & 98.36 \\
\hline $\mathbf{1 0}$ & 109,993 & 0.57 & 98.93 \\
\hline $\mathbf{1 1}$ & 49,580 & 0.26 & 99.18 \\
\hline $\mathbf{1 2}$ & 48,808 & 0.25 & 99.44 \\
\hline $\mathbf{1 3}$ & 4,295 & 0.02 & 99.46 \\
\hline $\mathbf{1 4}$ & 686 & 0 & 99.46 \\
\hline $\mathbf{1 5}$ & 64,533 & 0.33 & 99.79 \\
\hline $\mathbf{1 6}$ & 21,300 & 0.11 & 99.91 \\
\hline $\mathbf{1 7}$ & 5,355 & 0.03 & 99.93 \\
\hline $\mathbf{1 8}$ & 4,264 & 0.02 & 99.95 \\
\hline $\mathbf{1 9}$ & 8,731 & 0.05 & 100 \\
\hline Total & $\mathbf{1 9 , 3 2 1 , 1 9 6}$ & $\mathbf{1 0 0}$ & \\
\hline & & & \\
\hline
\end{tabular}


Table 10: Distribution of Matched Records by Matching Round, 2012

\begin{tabular}{|c|c|c|c|}
\hline Rounds & $\begin{array}{c}\text { Matched } \\
\text { Households }\end{array}$ & Percent of Total & $\begin{array}{l}\text { Cumulative } \\
\text { Percentage }\end{array}$ \\
\hline 1 & $13,391,873$ & 64.92 & 64.92 \\
\hline 2 & $1,980,457$ & 9.6 & 74.52 \\
\hline 3 & $2,489,216$ & 12.07 & 86.59 \\
\hline 4 & 863,669 & 4.19 & 90.78 \\
\hline 5 & 511,207 & 2.48 & 93.26 \\
\hline 6 & 203,764 & 0.99 & 94.24 \\
\hline 7 & 169,900 & 0.82 & 95.07 \\
\hline 8 & 187,607 & 0.91 & 95.98 \\
\hline 9 & 57,161 & 0.28 & 96.25 \\
\hline 10 & 41,657 & 0.2 & 96.46 \\
\hline 11 & 18,799 & 0.09 & 96.55 \\
\hline 12 & 15,388 & 0.07 & 96.62 \\
\hline 13 & 13,940 & 0.07 & 96.69 \\
\hline 14 & 6,278 & 0.03 & 96.72 \\
\hline 15 & 2,289 & 0.01 & 96.73 \\
\hline 16 & 72,701 & 0.35 & 97.08 \\
\hline 17 & 7,714 & 0.04 & 97.12 \\
\hline 18 & 25,314 & 0.12 & 97.24 \\
\hline 19 & 444,046 & 2.15 & 99.4 \\
\hline 20 & 28,115 & 0.14 & 99.53 \\
\hline 21 & 13,206 & 0.06 & 99.6 \\
\hline 22 & 643 & 0 & 99.6 \\
\hline 23 & 795 & 0 & 99.6 \\
\hline 24 & 72,466 & 0.35 & 99.95 \\
\hline 25 & 1,212 & 0.01 & 99.96 \\
\hline 26 & 8,215 & 0.04 & 100 \\
\hline Total & $20,627,632$ & 100 & \\
\hline
\end{tabular}


Table 11: Comparison of Mean and Median Values of Household Expenditure, 2005

\begin{tabular}{|l|c|c|c|c|c|c|}
\hline & \multicolumn{3}{|c|}{ Mean } & \multicolumn{3}{c|}{ Median } \\
\hline & $\begin{array}{c}\text { Matched } \\
\text { File }\end{array}$ & $\begin{array}{c}\text { HBS } \\
\mathbf{2 0 0 5}\end{array}$ & $\begin{array}{c}\text { Compliance } \\
\mathbf{( \% )}\end{array}$ & $\begin{array}{c}\text { Matched } \\
\text { File }\end{array}$ & $\begin{array}{c}\text { HBS } \\
\mathbf{2 0 0 5}\end{array}$ & $\begin{array}{c}\text { Compliance } \\
\text { (\%) }\end{array}$ \\
\hline $\begin{array}{l}\text { Total Household } \\
\text { Expenditure }\end{array}$ & 1101.18 & 1091.28 & $\mathbf{1 0 0 . 9 1}$ & 873.43 & 864.18 & $\mathbf{1 0 1 . 0 7}$ \\
\hline $\begin{array}{l}\text { Food } \\
\text { Expenditures }\end{array}$ & 266.87 & 271.46 & $\mathbf{9 8 . 3 1}$ & 234.34 & 237.30 & $\mathbf{9 8 . 7 5}$ \\
\hline Clothing & 68.60 & 67.74 & $\mathbf{1 0 1 . 2 8}$ & 30.00 & 28.49 & $\mathbf{1 0 5 . 3 0}$ \\
\hline Durables & 54.47 & 54.92 & $\mathbf{9 9 . 1 9}$ & 0.00 & 0.00 & $\cdot$ \\
\hline Nondurables & 20.31 & 20.63 & $\mathbf{9 8 . 4 5}$ & 12.25 & 12.50 & $\mathbf{9 8 . 0 0}$ \\
\hline Education & 28.87 & 26.57 & $\mathbf{1 0 8 . 6 7}$ & 0.35 & 0.30 & $\mathbf{1 1 6 . 6 7}$ \\
\hline
\end{tabular}

Table 12: Comparison of Mean and Median Values of Household Expenditure, 2008

\begin{tabular}{|l|c|c|c|c|c|c|}
\hline & \multicolumn{3}{|c|}{ Mean } & \multicolumn{3}{c|}{ Median } \\
\hline & $\begin{array}{c}\text { Matched } \\
\text { File }\end{array}$ & $\begin{array}{c}\text { HBS } \\
\mathbf{2 0 0 8}\end{array}$ & $\begin{array}{c}\text { Compliance } \\
\mathbf{( \% )}\end{array}$ & $\begin{array}{c}\text { Matched } \\
\text { File }\end{array}$ & $\begin{array}{c}\text { HBS } \\
\mathbf{2 0 0 8}\end{array}$ & $\begin{array}{c}\text { Compliance } \\
\text { (\%) }\end{array}$ \\
\hline $\begin{array}{l}\text { Total Household } \\
\text { Expenditure }\end{array}$ & 1622.05 & 1600.38 & $\mathbf{1 0 1 . 3 5}$ & 1338.01 & 1310.79 & $\mathbf{1 0 2 . 0 8}$ \\
\hline $\begin{array}{l}\text { Food } \\
\text { Expenditures }\end{array}$ & 368.01 & 362.32 & $\mathbf{1 0 1 . 5 7}$ & 321.96 & 319.45 & $\mathbf{1 0 0 . 7 9}$ \\
\hline Clothing & 87.81 & 86.61 & $\mathbf{1 0 1 . 3 9}$ & 35 & 35 & $\mathbf{1 0 0 . 0 0}$ \\
\hline Durables & 61.34 & 60.00 & $\mathbf{1 0 2 . 2 4}$ & 6.67 & 6.67 & $\mathbf{1 0 0 . 0 0}$ \\
\hline Nondurables & 27.95 & 27.90 & $\mathbf{1 0 0 . 1 7}$ & 17.5 & 17.4 & $\mathbf{1 0 0 . 5 7}$ \\
\hline Education & 38.89 & 39.33 & $\mathbf{9 8 . 8 8}$ & 1 & 1 & $\mathbf{1 0 0 . 0 0}$ \\
\hline
\end{tabular}


Table 13: Comparison of Mean and Median Household Expenditure, 2009

\begin{tabular}{|l|c|c|c|c|c|c|}
\hline & \multicolumn{3}{|c|}{ Mean } & \multicolumn{3}{c|}{ Median } \\
\hline & $\begin{array}{c}\text { Matched } \\
\text { File }\end{array}$ & $\begin{array}{c}\text { HBS } \\
\mathbf{2 0 0 9}\end{array}$ & $\begin{array}{c}\text { Compliance } \\
\mathbf{( \% )}\end{array}$ & $\begin{array}{c}\text { Matched } \\
\text { File }\end{array}$ & $\begin{array}{c}\text { HBS } \\
\mathbf{2 0 0 9}\end{array}$ & $\begin{array}{c}\text { Compliance } \\
\text { (\%) }\end{array}$ \\
\hline $\begin{array}{l}\text { Total Household } \\
\text { Expenditure }\end{array}$ & 1667.78 & 1687.75 & $\mathbf{9 8 . 8 2}$ & 1383.61 & 1402.19 & $\mathbf{9 8 . 6 7}$ \\
\hline $\begin{array}{l}\text { Food } \\
\text { Expenditures }\end{array}$ & 386.48 & 388.19 & $\mathbf{9 9 . 5 6}$ & 330.55 & 331.6 & $\mathbf{9 9 . 6 8}$ \\
\hline Clothing & 86.49 & 85.60 & $\mathbf{1 0 1 . 0 3}$ & 35 & 34.5 & $\mathbf{1 0 1 . 4 5}$ \\
\hline Durables & 69.41 & 69.37 & $\mathbf{1 0 0 . 0 6}$ & 10.9 & 10.83 & $\mathbf{1 0 0 . 6 5}$ \\
\hline Nondurables & 31.19 & 31.00 & $\mathbf{1 0 0 . 5 9}$ & 19.5 & 19.25 & $\mathbf{1 0 1 . 3 0}$ \\
\hline Education & 41.13 & 41.23 & $\mathbf{9 9 . 7 5}$ & 1.25 & 1.25 & $\mathbf{1 0 0 . 0 0}$ \\
\hline
\end{tabular}

Table 14: Comparison of Mean and Median Household Expenditure, 2012

\begin{tabular}{|l|c|c|c|c|c|c|}
\hline & \multicolumn{3}{|c|}{ Mean } & \multicolumn{3}{c|}{ Median } \\
\hline & $\begin{array}{c}\text { Matched } \\
\text { File }\end{array}$ & $\begin{array}{c}\text { HBS } \\
\mathbf{2 0 1 2}\end{array}$ & $\begin{array}{c}\text { Compliance } \\
\mathbf{( \% )}\end{array}$ & $\begin{array}{c}\text { Matched } \\
\text { File }\end{array}$ & $\begin{array}{c}\text { HBS } \\
\mathbf{2 0 1 2}\end{array}$ & $\begin{array}{c}\text { Compliance } \\
\text { (\%) }\end{array}$ \\
\hline $\begin{array}{l}\text { Total Household } \\
\text { Expenditure }\end{array}$ & 2351.25 & 2365.56 & $\mathbf{9 9 . 4 0}$ & 1849.15 & 1868.24 & $\mathbf{9 8 . 9 8}$ \\
\hline $\begin{array}{l}\text { Food } \\
\text { Expenditures }\end{array}$ & 463.12 & 463.74 & $\mathbf{9 9 . 8 7}$ & 394.00 & 396.06 & $\mathbf{9 9 . 4 8}$ \\
\hline Clothing & 124.75 & 127.00 & $\mathbf{9 8 . 2 2}$ & 51.95 & 54.40 & $\mathbf{9 5 . 5 0}$ \\
\hline Durables & 117.09 & 116.13 & $\mathbf{1 0 0 . 8 3}$ & 20.17 & 20.83 & $\mathbf{9 6 . 8 3}$ \\
\hline Nondurables & 38.06 & 38.15 & $\mathbf{9 9 . 7 7}$ & 22.99 & 23.00 & $\mathbf{9 9 . 9 6}$ \\
\hline Education & 71.13 & 70.08 & $\mathbf{1 0 1 . 5 0}$ & 1.5 & 1.5 & $\mathbf{1 0 0 . 0 0}$ \\
\hline
\end{tabular}


Table 15: Comparison of Distribution of Per Capita Disposable Income by Deciles, 2005

\begin{tabular}{|c|c|c|c|}
\hline & Mean & Mean & \\
\hline Deciles & Matched File & HBS 2005 & Compliance \\
\hline 1 & 737.92 & 682.72 & 108.08 \\
\hline 2 & 1375.48 & 1361.78 & 101.01 \\
\hline 3 & 1877.31 & 1896.36 & 99.00 \\
\hline 4 & 2412.13 & 2407.33 & 100.20 \\
\hline 5 & 3005.48 & 2945.29 & 102.04 \\
\hline 6 & 3689.45 & 3552.61 & 103.85 \\
\hline 7 & 4574.85 & 4278.26 & 106.93 \\
\hline 8 & 5771.71 & 5243.13 & 110.08 \\
\hline 9 & 7829.71 & 6850.72 & 114.29 \\
\hline 10 & 17086.16 & 14133.75 & 120.89 \\
\hline Turkey & 4834.78 & 4334.18 & 111.55 \\
\hline Deciles & Matched File & HBS 2009 & Compliance \\
\hline 1 & 1373.59 & 1214.42 & 113.11 \\
\hline 2 & 2363.13 & 2252.01 & 104.93 \\
\hline 3 & 3180.06 & 3069.52 & 103.60 \\
\hline 4 & 4004.44 & 3839.78 & 104.29 \\
\hline 5 & 4854.00 & 4641.11 & 104.59 \\
\hline 6 & 5844.43 & 5543.80 & 105.42 \\
\hline 7 & 7084.07 & 6680.88 & 106.04 \\
\hline 8 & 8814.43 & 8307.52 & 106.10 \\
\hline 9 & 11770.88 & 11170.39 & 105.38 \\
\hline 10 & 24693.35 & 23945.22 & 103.12 \\
\hline Turkey & 7397.53 & 7063.82 & 104.72 \\
\hline Deciles & Matched File & HBS 2012 & Compliance \\
\hline 1 & 1972.75 & 2011.67 & 98.07 \\
\hline 2 & 3317.40 & 3465.98 & 95.71 \\
\hline 3 & 4398.57 & 4554.80 & 96.57 \\
\hline 4 & 5470.37 & 5600.96 & 97.67 \\
\hline 5 & 6659.78 & 6718.67 & 99.12 \\
\hline 6 & 7911.66 & 8003.08 & 98.86 \\
\hline 7 & 9543.98 & 9566.02 & 99.77 \\
\hline 8 & 11865.98 & 11847.50 & 100.16 \\
\hline 9 & 15859.15 & 15740.89 & 100.75 \\
\hline 10 & 33706.94 & 32078.56 & 105.08 \\
\hline Total & 10069.50 & 9957.62 & 101.12 \\
\hline
\end{tabular}


Table 16: Mean of Some Household Monthly Expenditure by Quintile, 2005

\begin{tabular}{|c|c|c|c|}
\hline & $\begin{array}{l}\text { Total Household } \\
\text { Expenditure }\end{array}$ & & \\
\hline Deciles & HBS 2005 & Matched File & Compliance \\
\hline 1 & 532.50 & 526.08 & 98.79 \\
\hline 2 & 659.16 & 677.20 & 102.74 \\
\hline 3 & 768.67 & 768.86 & 100.03 \\
\hline 4 & 866.48 & 863.05 & 99.60 \\
\hline 5 & 929.19 & 943.75 & 101.57 \\
\hline 6 & 997.96 & 1050.90 & 105.30 \\
\hline 7 & 1150.34 & 1212.65 & 105.42 \\
\hline 8 & 1297.80 & 1290.72 & 99.45 \\
\hline 9 & 1460.71 & 1541.18 & 105.51 \\
\hline 10 & 2250.57 & 2138.54 & 95.02 \\
\hline \multirow[t]{2}{*}{ Total } & 1091.22 & 1101.18 & 100.91 \\
\hline & Food Expenditures & & \\
\hline Deciles & HBS 2005 & Matched File & Compliance \\
\hline 1 & 230.59 & 219.24 & 95.08 \\
\hline 2 & 238.56 & 231.59 & 97.08 \\
\hline 3 & 238.40 & 232.94 & 97.71 \\
\hline 4 & 259.05 & 235.14 & 90.77 \\
\hline 5 & 260.22 & 254.62 & 97.85 \\
\hline 6 & 268.62 & 274.47 & 102.18 \\
\hline 7 & 279.28 & 279.84 & 100.20 \\
\hline 8 & 299.55 & 284.56 & 95.00 \\
\hline 9 & 300.26 & 314.77 & 104.83 \\
\hline 10 & 340.18 & 341.58 & 100.41 \\
\hline \multirow[t]{2}{*}{ Total } & 271.46 & 266.87 & 98.31 \\
\hline & Clothing & & \\
\hline Deciles & HBS 2005 & Matched File & Compliance \\
\hline 1 & 38.92 & 36.10 & 92.75 \\
\hline 2 & 43.21 & 45.06 & 104.28 \\
\hline 3 & 51.59 & 49.51 & 95.97 \\
\hline 4 & 53.20 & 52.26 & 98.22 \\
\hline 5 & 59.56 & 60.52 & 101.61 \\
\hline 6 & 59.33 & 63.71 & 107.38 \\
\hline 7 & 67.12 & 70.48 & 105.01 \\
\hline 8 & 73.34 & 74.87 & 102.08 \\
\hline 9 & 91.13 & 102.94 & 112.96 \\
\hline 10 & 140.03 & 130.67 & 93.31 \\
\hline Total & 67.74 & 68.60 & 101.28 \\
\hline
\end{tabular}


Table 17: Mean of Some Household Expenditure by Quintile, 2005

\begin{tabular}{|c|c|c|c|}
\hline & Durables & & \\
\hline Deciles & HBS 2005 & Matched File & Compliance \\
\hline 1 & 24.38 & 18.02 & 73.94 \\
\hline 2 & 31.83 & 28.99 & 91.07 \\
\hline 3 & 40.73 & 41.65 & 102.26 \\
\hline 4 & 43.74 & 35.23 & 80.54 \\
\hline 5 & 44.41 & 53.90 & 121.38 \\
\hline 6 & 51.92 & 52.73 & 101.56 \\
\hline 7 & 65.17 & 73.08 & 112.14 \\
\hline 8 & 73.07 & 66.89 & 91.54 \\
\hline 9 & 68.03 & 69.13 & 101.61 \\
\hline 10 & 105.83 & 105.16 & 99.37 \\
\hline \multirow[t]{2}{*}{ Total } & 54.91 & 54.47 & 99.21 \\
\hline & Nondurables & & \\
\hline Deciles & HBS 2005 & Matched File & Compliance \\
\hline 1 & 11.97 & 11.89 & 99.33 \\
\hline 2 & 14.82 & 15.23 & 102.81 \\
\hline 3 & 19.00 & 16.48 & 86.73 \\
\hline 4 & 17.31 & 16.68 & 96.34 \\
\hline 5 & 17.85 & 18.40 & 103.09 \\
\hline 6 & 20.85 & 19.90 & 95.45 \\
\hline 7 & 21.08 & 19.33 & 91.70 \\
\hline 8 & 21.97 & 25.19 & 114.68 \\
\hline 9 & 25.97 & 25.52 & 98.27 \\
\hline 10 & 35.49 & 34.49 & 97.18 \\
\hline \multirow[t]{2}{*}{ Total } & 20.63 & 20.31 & 98.45 \\
\hline & Housing & & \\
\hline Deciles & HBS 2005 & Matched File & Compliance \\
\hline 1 & 22.56 & 30.74 & 136.27 \\
\hline 2 & 41.10 & 47.39 & 115.31 \\
\hline 3 & 44.05 & 51.94 & 117.90 \\
\hline 4 & 48.97 & 69.19 & 141.29 \\
\hline 5 & 55.44 & 46.75 & 84.32 \\
\hline 6 & 55.55 & 52.91 & 95.25 \\
\hline 7 & 65.88 & 59.76 & 90.72 \\
\hline 8 & 59.53 & 63.70 & 107.00 \\
\hline 9 & 69.16 & 78.05 & 112.86 \\
\hline 10 & 106.46 & 106.92 & 100.44 \\
\hline Total & 56.86 & 60.73 & 106.80 \\
\hline
\end{tabular}


Table 18: Mean of Some Household Monthly Expenditure by Quintile, 2008

\begin{tabular}{|c|c|c|c|}
\hline & Total Household Expenditure & & \\
\hline Deciles & HBS 2008 & $\begin{array}{l}\text { Matched } \\
\text { File }\end{array}$ & Compliance \\
\hline 1 & 776.72 & 854.78 & 110.05 \\
\hline 2 & 1003.43 & 1028.69 & 97.54 \\
\hline 3 & 1182.84 & 1150.79 & 102.79 \\
\hline 4 & 1343.72 & 1308.88 & 102.66 \\
\hline 5 & 1463.03 & 1391.81 & 105.12 \\
\hline 6 & 1550.75 & 1486.18 & 104.34 \\
\hline 7 & 1755.58 & 1675.18 & 104.80 \\
\hline 8 & 1903.40 & 1773.96 & 107.30 \\
\hline 9 & 2101.67 & 2180.59 & 96.38 \\
\hline 10 & 3177.92 & 3154.54 & 100.74 \\
\hline \multirow[t]{2}{*}{ Total } & 1625.72 & 1600.38 & 101.58 \\
\hline & Food Expenditures & & \\
\hline Deciles & HBS 2008 & $\begin{array}{c}\text { Matched } \\
\text { File }\end{array}$ & Compliance \\
\hline 1 & 294.89 & 304.80 & 103.36 \\
\hline 2 & 312.76 & 312.26 & 99.84 \\
\hline 3 & 323.22 & 321.20 & 99.37 \\
\hline 4 & 355.76 & 333.19 & 93.66 \\
\hline 5 & 360.64 & 346.51 & 96.08 \\
\hline 6 & 375.63 & 356.82 & 94.99 \\
\hline 7 & 385.86 & 375.81 & 97.40 \\
\hline 8 & 399.33 & 385.01 & 96.41 \\
\hline 9 & 401.04 & 413.71 & 103.16 \\
\hline 10 & 471.07 & 474.00 & 100.62 \\
\hline \multirow[t]{2}{*}{ Total } & 368.01 & 362.32 & 98.46 \\
\hline & Clothing & & \\
\hline Deciles & HBS 2008 & $\begin{array}{l}\text { Matched } \\
\text { File }\end{array}$ & Compliance \\
\hline 1 & 43.03 & 44.94 & 104.44 \\
\hline 2 & 51.76 & 50.20 & 97.00 \\
\hline 3 & 55.40 & 52.95 & 95.58 \\
\hline 4 & 67.98 & 69.07 & 101.60 \\
\hline 5 & 81.07 & 79.02 & 97.47 \\
\hline 6 & 78.22 & 77.57 & 99.18 \\
\hline 7 & 86.82 & 84.09 & 96.85 \\
\hline 8 & 106.13 & 86.82 & 81.80 \\
\hline 9 & 102.43 & 129.65 & 126.58 \\
\hline 10 & 205.41 & 191.84 & 93.39 \\
\hline Total & 87.81 & 86.61 & 98.63 \\
\hline
\end{tabular}


Table 19: Mean of Some Household Expenditure by Quintile, 2008 (continued)

\begin{tabular}{|c|c|c|c|}
\hline & Durables & & \\
\hline Deciles & HBS 2008 & Matched File & Compliance \\
\hline 1 & 33.02 & 37.79 & 114.44 \\
\hline 2 & 34.90 & 31.80 & 91.12 \\
\hline 3 & 44.14 & 38.78 & 87.87 \\
\hline 4 & 50.39 & 57.26 & 113.65 \\
\hline 5 & 56.65 & 54.00 & 95.32 \\
\hline 6 & 62.42 & 54.03 & 86.56 \\
\hline 7 & 63.95 & 64.81 & 101.34 \\
\hline 8 & 77.19 & 73.32 & 95.00 \\
\hline 9 & 83.70 & 81.72 & 97.64 \\
\hline 10 & 107.08 & 106.47 & 99.43 \\
\hline \multirow[t]{2}{*}{ Total } & 61.34 & 60.00 & 97.81 \\
\hline & Nondurables & & \\
\hline Deciles & HBS 2008 & Matched File & Compliance \\
\hline 1 & 18.15 & 18.55 & 102.24 \\
\hline 2 & 17.99 & 18.95 & 105.32 \\
\hline 3 & 19.96 & 20.79 & 104.15 \\
\hline 4 & 26.79 & 23.43 & 87.47 \\
\hline 5 & 27.24 & 25.75 & 94.53 \\
\hline 6 & 29.46 & 26.95 & 91.50 \\
\hline 7 & 29.99 & 31.27 & 104.25 \\
\hline 8 & 32.34 & 29.61 & 91.56 \\
\hline 9 & 32.31 & 40.28 & 124.68 \\
\hline 10 & 45.27 & 43.43 & 95.93 \\
\hline \multirow[t]{2}{*}{ Total } & 27.95 & 27.90 & 99.83 \\
\hline & Housing & & \\
\hline Deciles & HBS 2008 & Matched File & Compliance \\
\hline 1 & 40.87 & 48.35 & 118.31 \\
\hline 2 & 73.12 & 70.38 & 96.24 \\
\hline 3 & 86.63 & 83.34 & 96.20 \\
\hline 4 & 87.21 & 85.08 & 97.55 \\
\hline 5 & 109.43 & 95.42 & 87.19 \\
\hline 6 & 95.45 & 95.20 & 99.74 \\
\hline 7 & 99.39 & 90.19 & 90.75 \\
\hline 8 & 92.73 & 87.16 & 94.00 \\
\hline 9 & 121.47 & 107.50 & 88.50 \\
\hline 10 & 131.80 & 141.45 & 107.31 \\
\hline Total & 93.80 & 90.40 & 96.37 \\
\hline
\end{tabular}


Table 20: Mean of Some Household Monthly Expenditure by Quintile, 2009

\begin{tabular}{|c|c|c|c|}
\hline & $\begin{array}{l}\text { Total Household } \\
\text { Expenditure }\end{array}$ & & \\
\hline Deciles & HBS 2009 & Matched File & Compliance \\
\hline 1 & 858.74 & 918.78 & 106.99 \\
\hline 2 & 1025.75 & 1114.75 & 92.02 \\
\hline 3 & 1244.88 & 1264.94 & 98.41 \\
\hline 4 & 1362.82 & 1329.02 & 102.54 \\
\hline 5 & 1486.84 & 1428.35 & 104.09 \\
\hline 6 & 1620.42 & 1580.24 & 102.54 \\
\hline 7 & 1764.50 & 1734.58 & 101.72 \\
\hline 8 & 2030.01 & 1985.98 & 102.22 \\
\hline 9 & 2267.24 & 2193.40 & 103.37 \\
\hline 10 & 3218.55 & 3128.71 & 102.87 \\
\hline \multirow[t]{2}{*}{ Total } & 1687.75 & 1667.78 & 101.20 \\
\hline & Food Expenditures & & \\
\hline Deciles & HBS 2009 & Matched File & Compliance \\
\hline 1 & 333.77 & 331.93 & 99.45 \\
\hline 2 & 314.12 & 333.80 & 94.10 \\
\hline 3 & 348.67 & 359.78 & 96.91 \\
\hline 4 & 381.03 & 355.75 & 107.11 \\
\hline 5 & 373.40 & 354.93 & 105.20 \\
\hline 6 & 408.78 & 389.24 & 105.02 \\
\hline 7 & 398.36 & 390.58 & 101.99 \\
\hline 8 & 417.66 & 428.87 & 97.39 \\
\hline 9 & 435.91 & 442.35 & 98.54 \\
\hline 10 & 470.29 & 477.66 & 98.46 \\
\hline \multirow[t]{2}{*}{ Total } & 388.19 & 386.48 & 100.44 \\
\hline & Clothing & & \\
\hline Deciles & HBS 2009 & Matched File & Compliance \\
\hline 1 & 52.71 & 51.04 & 96.84 \\
\hline 2 & 50.49 & 53.29 & 94.74 \\
\hline 3 & 53.19 & 62.15 & 85.58 \\
\hline 4 & 66.18 & 63.30 & 104.56 \\
\hline 5 & 68.23 & 66.78 & 102.16 \\
\hline 6 & 75.11 & 73.73 & 101.86 \\
\hline 7 & 81.08 & 76.18 & 106.43 \\
\hline 8 & 104.54 & 110.25 & 94.82 \\
\hline 9 & 123.06 & 118.10 & 104.20 \\
\hline 10 & 181.57 & 190.08 & 95.52 \\
\hline Total & 85.60 & 86.49 & 98.98 \\
\hline
\end{tabular}


Table 21: Mean of Some Household Expenditure by Quintile, 2009 (continued)

\begin{tabular}{|c|c|c|c|}
\hline & Durables & & \\
\hline Deciles & HBS 2009 & Matched File & Compliance \\
\hline 1 & 31.01 & 30.00 & 96.74 \\
\hline 2 & 34.67 & 38.56 & 89.91 \\
\hline 3 & 49.52 & 48.42 & 102.28 \\
\hline 4 & 46.85 & 50.73 & 92.35 \\
\hline 5 & 59.68 & 59.15 & 100.91 \\
\hline 6 & 64.02 & 60.35 & 106.07 \\
\hline 7 & 84.29 & 77.69 & 108.50 \\
\hline 8 & 83.16 & 86.48 & 96.16 \\
\hline 9 & 101.97 & 91.55 & 111.39 \\
\hline 10 & 138.61 & 151.25 & 91.64 \\
\hline \multirow[t]{2}{*}{ Total } & 69.37 & 69.41 & 99.94 \\
\hline & Nondurables & & \\
\hline Deciles & HBS 2009 & Matched File & Compliance \\
\hline 1 & 19.80 & 19.95 & 100.77 \\
\hline 2 & 22.54 & 26.43 & 85.30 \\
\hline 3 & 22.09 & 23.31 & 94.76 \\
\hline 4 & 27.26 & 26.04 & 104.67 \\
\hline 5 & 26.56 & 25.94 & 102.39 \\
\hline 6 & 29.98 & 29.69 & 100.96 \\
\hline 7 & 29.81 & 28.45 & 104.77 \\
\hline 8 & 36.39 & 38.58 & 94.31 \\
\hline 9 & 41.08 & 38.21 & 107.51 \\
\hline 10 & 54.57 & 55.28 & 98.72 \\
\hline \multirow[t]{2}{*}{ Total } & 31.00 & 31.19 & 99.41 \\
\hline & Housing & & \\
\hline Deciles & HBS 2009 & Matched File & Compliance \\
\hline 1 & 58.83 & 73.46 & 124.87 \\
\hline 2 & 82.34 & 93.31 & 88.25 \\
\hline 3 & 102.13 & 95.82 & 106.59 \\
\hline 4 & 86.59 & 84.99 & 101.88 \\
\hline 5 & 93.61 & 91.68 & 102.11 \\
\hline 6 & 94.62 & 87.63 & 107.98 \\
\hline 7 & 100.47 & 105.64 & 95.11 \\
\hline 8 & 105.62 & 89.08 & 118.57 \\
\hline 9 & 129.35 & 112.28 & 115.20 \\
\hline 10 & 191.04 & 185.71 & 102.87 \\
\hline Total & 104.45 & 101.96 & 102.44 \\
\hline
\end{tabular}


Table 22: Mean of Some Household Monthly Expenditure by Quintile, 2012

\begin{tabular}{|c|c|c|c|}
\hline & Total Household Expenditure & & \\
\hline Deciles & HBS 2012 & Matched File & Compliance \\
\hline 1 & 1253.93 & 1355.85 & 108.13 \\
\hline 2 & 1536.70 & 1549.65 & 99.16 \\
\hline 3 & 1714.28 & 1726.47 & 99.29 \\
\hline 4 & 1853.92 & 1878.90 & 98.67 \\
\hline 5 & 1990.89 & 2017.97 & 98.66 \\
\hline 6 & 2245.79 & 2171.91 & 103.40 \\
\hline 7 & 2413.86 & 2318.69 & 104.10 \\
\hline 8 & 2627.22 & 2512.32 & 104.57 \\
\hline 9 & 3210.51 & 3243.18 & 98.99 \\
\hline 10 & 4810.06 & 4738.80 & 101.50 \\
\hline \multirow[t]{2}{*}{ Total } & 2365.56 & 2351.25 & 100.61 \\
\hline & Food Expenditures & & \\
\hline Deciles & HBS 2012 & Matched File & Compliance \\
\hline 1 & 387.29 & 375.84 & 97.04 \\
\hline 2 & 397.04 & 403.57 & 98.38 \\
\hline 3 & 421.50 & 409.33 & 102.97 \\
\hline 4 & 437.30 & 431.06 & 101.45 \\
\hline 5 & 439.09 & 445.71 & 98.51 \\
\hline 6 & 486.40 & 490.21 & 99.22 \\
\hline 7 & 486.50 & 473.56 & 102.73 \\
\hline 8 & 507.86 & 494.18 & 102.77 \\
\hline 9 & 514.97 & 520.93 & 98.86 \\
\hline 10 & 559.54 & 586.86 & 95.34 \\
\hline \multirow[t]{2}{*}{ Total } & 463.74 & 463.12 & 100.13 \\
\hline & Clothing & & \\
\hline Deciles & HBS 2012 & Matched File & Compliance \\
\hline 1 & 79.16 & 72.29 & 91.31 \\
\hline 2 & 70.98 & 72.69 & 97.65 \\
\hline 3 & 78.87 & 76.74 & 102.78 \\
\hline 4 & 94.62 & 108.62 & 87.11 \\
\hline 5 & 107.90 & 102.92 & 104.84 \\
\hline 6 & 108.96 & 114.25 & 95.37 \\
\hline 7 & 130.57 & 110.98 & 117.65 \\
\hline 8 & 140.55 & 129.24 & 108.75 \\
\hline 9 & 180.90 & 183.56 & 98.55 \\
\hline 10 & 277.62 & 276.26 & 100.49 \\
\hline Total & 127.00 & 124.75 & 101.81 \\
\hline
\end{tabular}


Table 23: Mean of Some Household Expenditure by Quintile, 2012 (continued)

\begin{tabular}{|c|c|c|c|}
\hline & Durables & & \\
\hline Deciles & HBS 2012 & Matched File & Compliance \\
\hline 1 & 51.97 & 53.76 & 103.44 \\
\hline 2 & 53.52 & 54.05 & 99.01 \\
\hline 3 & 79.32 & 78.85 & 100.59 \\
\hline 4 & 80.96 & 83.22 & 97.28 \\
\hline 5 & 103.65 & 110.37 & 93.91 \\
\hline 6 & 108.26 & 106.20 & 101.94 \\
\hline 7 & 131.82 & 124.28 & 106.07 \\
\hline 8 & 127.11 & 126.84 & 100.22 \\
\hline 9 & 174.17 & 167.66 & 103.88 \\
\hline 10 & 250.61 & 265.80 & 94.29 \\
\hline \multirow[t]{2}{*}{ Total } & 116.13 & 117.09 & 99.17 \\
\hline & Nondurables & & \\
\hline Deciles & HBS 2012 & Matched File & Compliance \\
\hline 1 & 24.91 & 24.79 & 99.51 \\
\hline 2 & 23.29 & 24.38 & 95.54 \\
\hline 3 & 26.92 & 27.34 & 98.47 \\
\hline 4 & 34.63 & 32.57 & 106.35 \\
\hline 5 & 36.46 & 37.64 & 96.87 \\
\hline 6 & 41.44 & 38.94 & 106.40 \\
\hline 7 & 40.38 & 43.31 & 93.24 \\
\hline 8 & 42.67 & 41.93 & 101.77 \\
\hline 9 & 46.86 & 47.57 & 98.50 \\
\hline 10 & 63.97 & 62.19 & 102.86 \\
\hline \multirow[t]{2}{*}{ Total } & 38.15 & 38.06 & 100.23 \\
\hline & Housing & & \\
\hline Deciles & HBS 2012 & Matched File & Compliance \\
\hline 1 & 84.24 & 103.16 & 122.45 \\
\hline 2 & 118.72 & 100.46 & 118.17 \\
\hline 3 & 122.19 & 124.56 & 98.10 \\
\hline 4 & 119.66 & 118.41 & 101.05 \\
\hline 5 & 117.62 & 127.51 & 92.24 \\
\hline 6 & 132.15 & 116.10 & 113.82 \\
\hline 7 & 132.82 & 118.87 & 111.74 \\
\hline 8 & 134.88 & 137.24 & 98.28 \\
\hline 9 & 170.60 & 175.44 & 97.24 \\
\hline 10 & 244.55 & 230.49 & 106.10 \\
\hline Total & 137.74 & 135.22 & 101.86 \\
\hline
\end{tabular}


Table 24: Gini Coefficient of Total Household Expenditure

\begin{tabular}{|l|c|c|c|c|}
\hline & $\mathbf{2 0 0 5}$ & $\mathbf{2 0 0 8}$ & $\mathbf{2 0 0 9}$ & $\mathbf{2 0 1 2}$ \\
\hline HBS & 0.367 & 0.344 & 0.345 & 0.366 \\
\hline Matched File & 0.367 & 0.348 & 0.345 & 0.368 \\
\hline
\end{tabular}

Table 25: Gini Coefficient of Disposable Household Income

\begin{tabular}{|l|c|c|c|c|}
\hline & $\mathbf{2 0 0 5}$ & $\mathbf{2 0 0 8}$ & $\mathbf{2 0 0 9}$ & $\mathbf{2 0 1 2}$ \\
\hline HBS & 0.382 & 0.380 & 0.387 & 0.378 \\
\hline Matched File & 0.403 & 0.394 & 0.380 & 0.382 \\
\hline
\end{tabular}


Figure 1: Difference between Lorenz Curves of Household Expenditure (Match/HBS), 2005

Difference Between Lorenz Curves of Household Expenditure Matched File\&HBS 2005

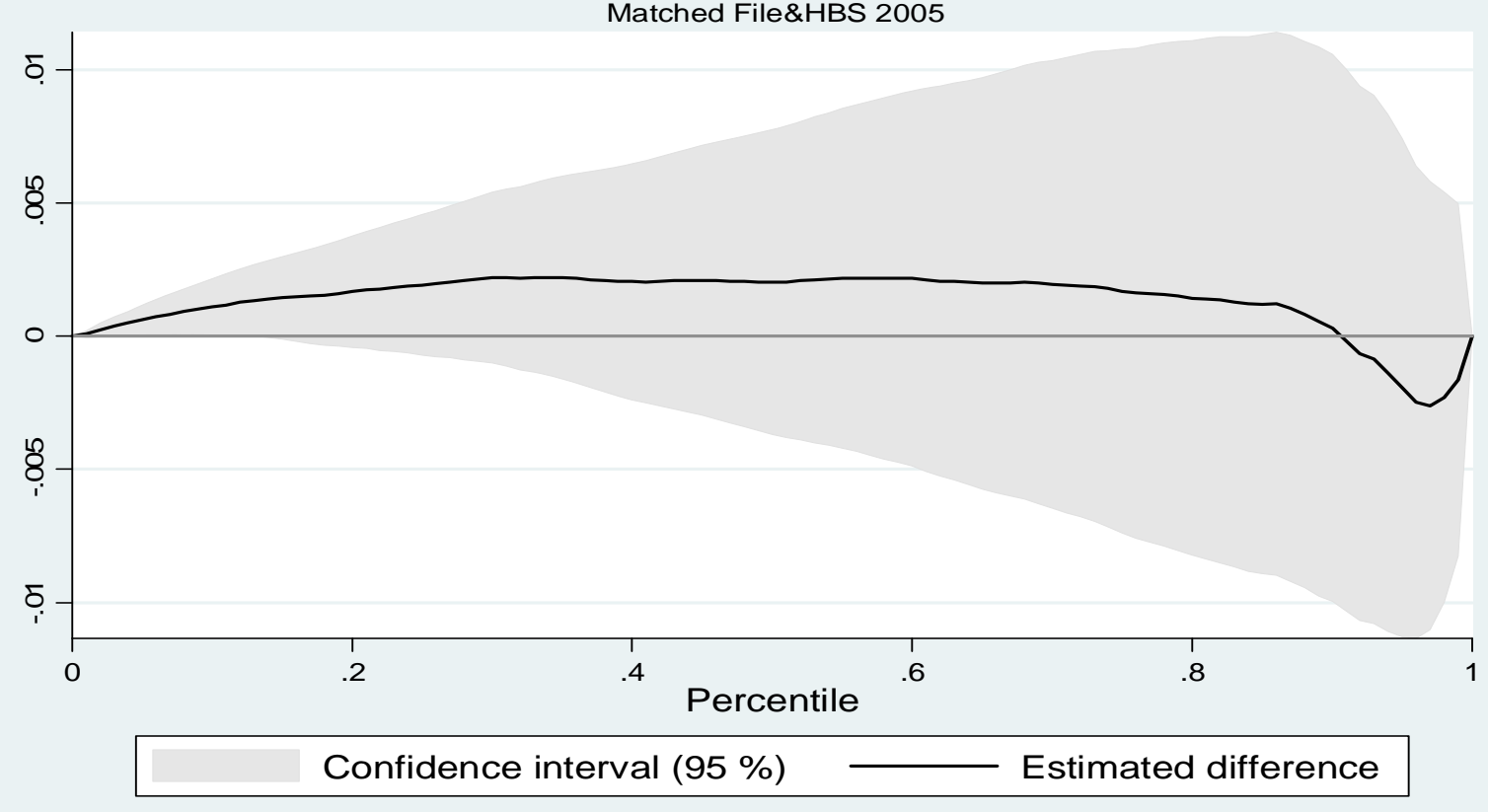

Figure 2: Difference between Lorenz Curves of Household Expenditure (Match/HBS), 2012

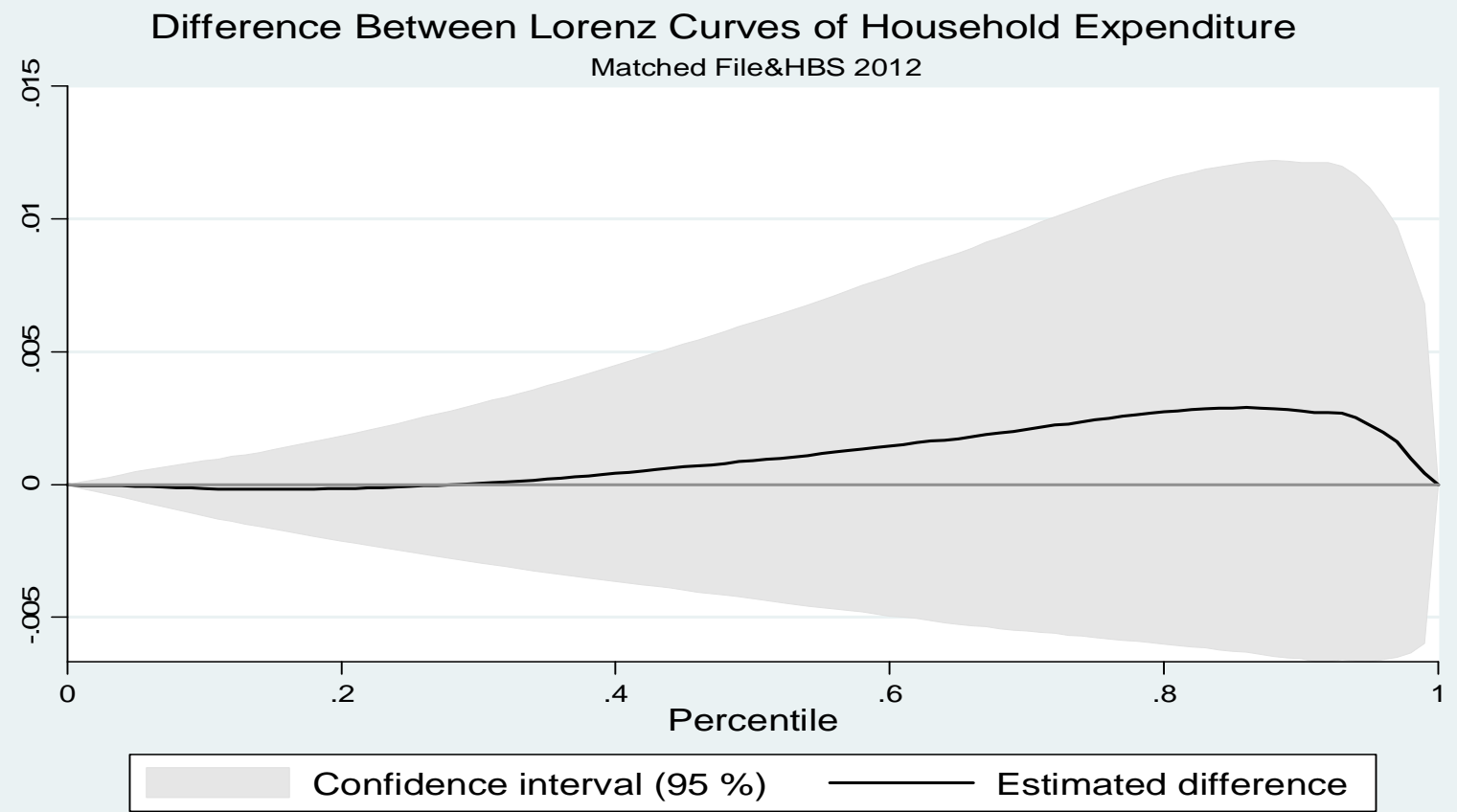


Figure 3: Comparison of Distribution of Household Expenditure

\section{Comparison of Distribution of Household Expenditure}
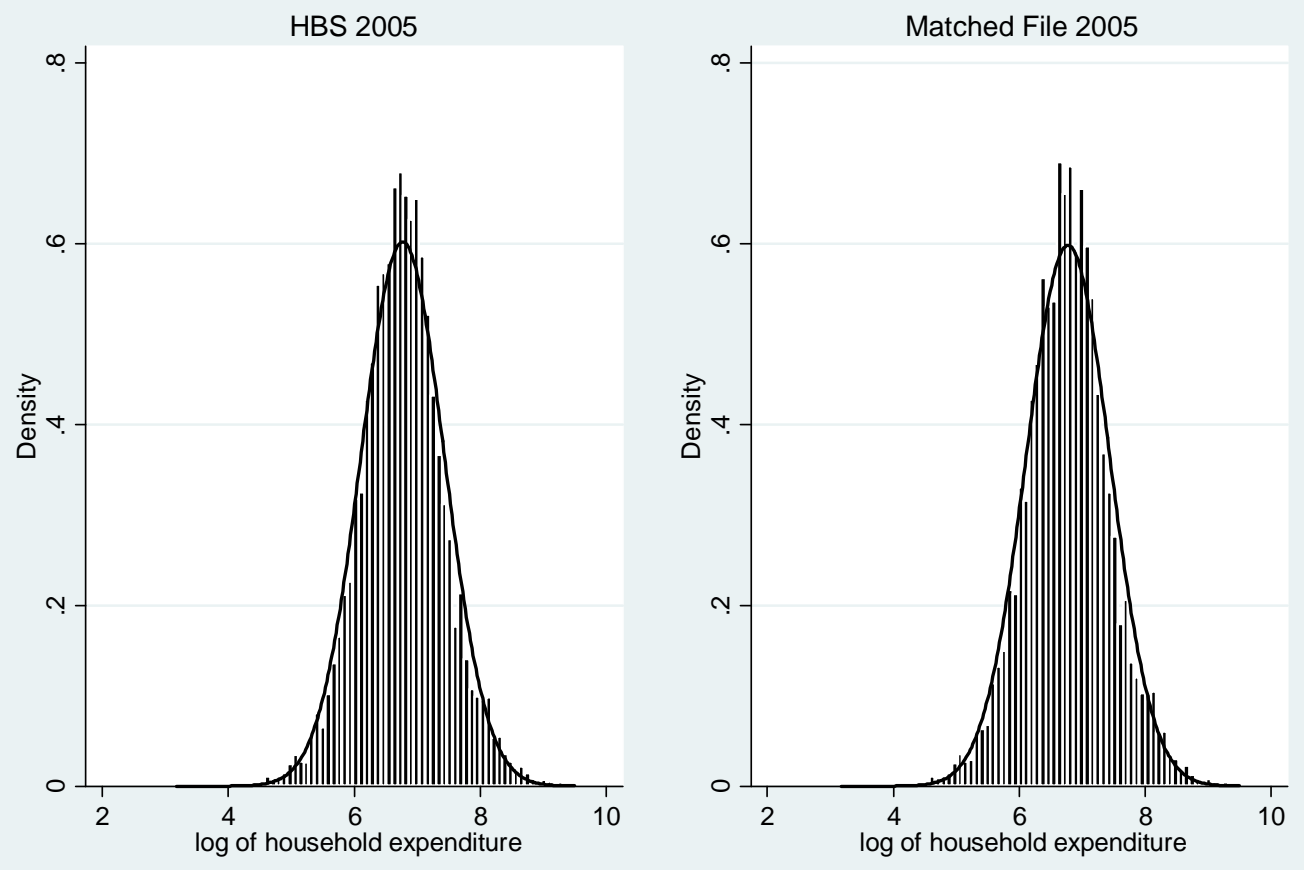

Figure 4: Comparison of Distribution of Household Expenditure (log)

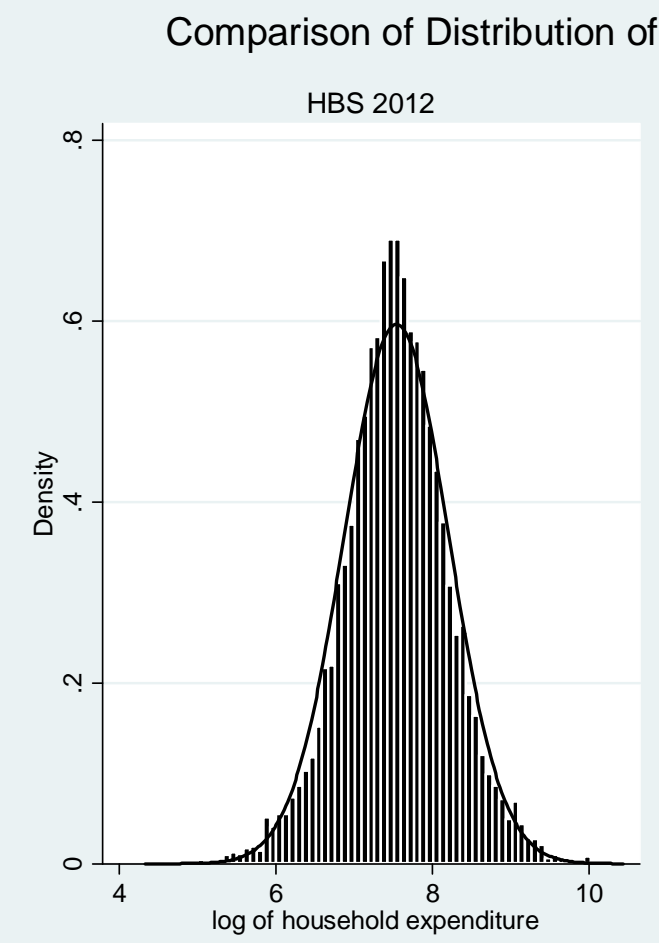

of Household Expenditure (log)

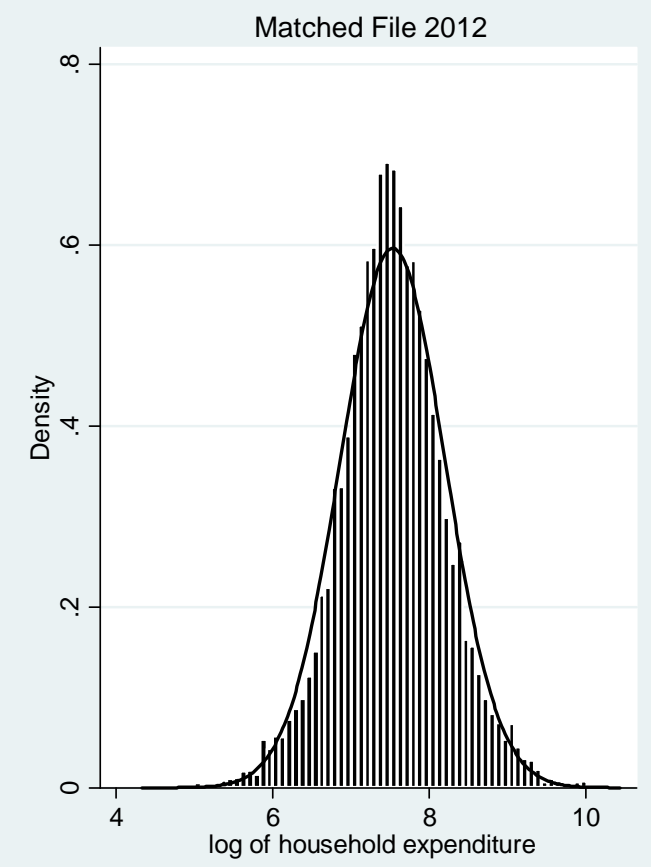


Figure 5: Ratio of Mean Household Expenditure by Category (Match/HBS), 2005

Ratio of Mean Household Expenditure by Category

(Match/HBS 2005)

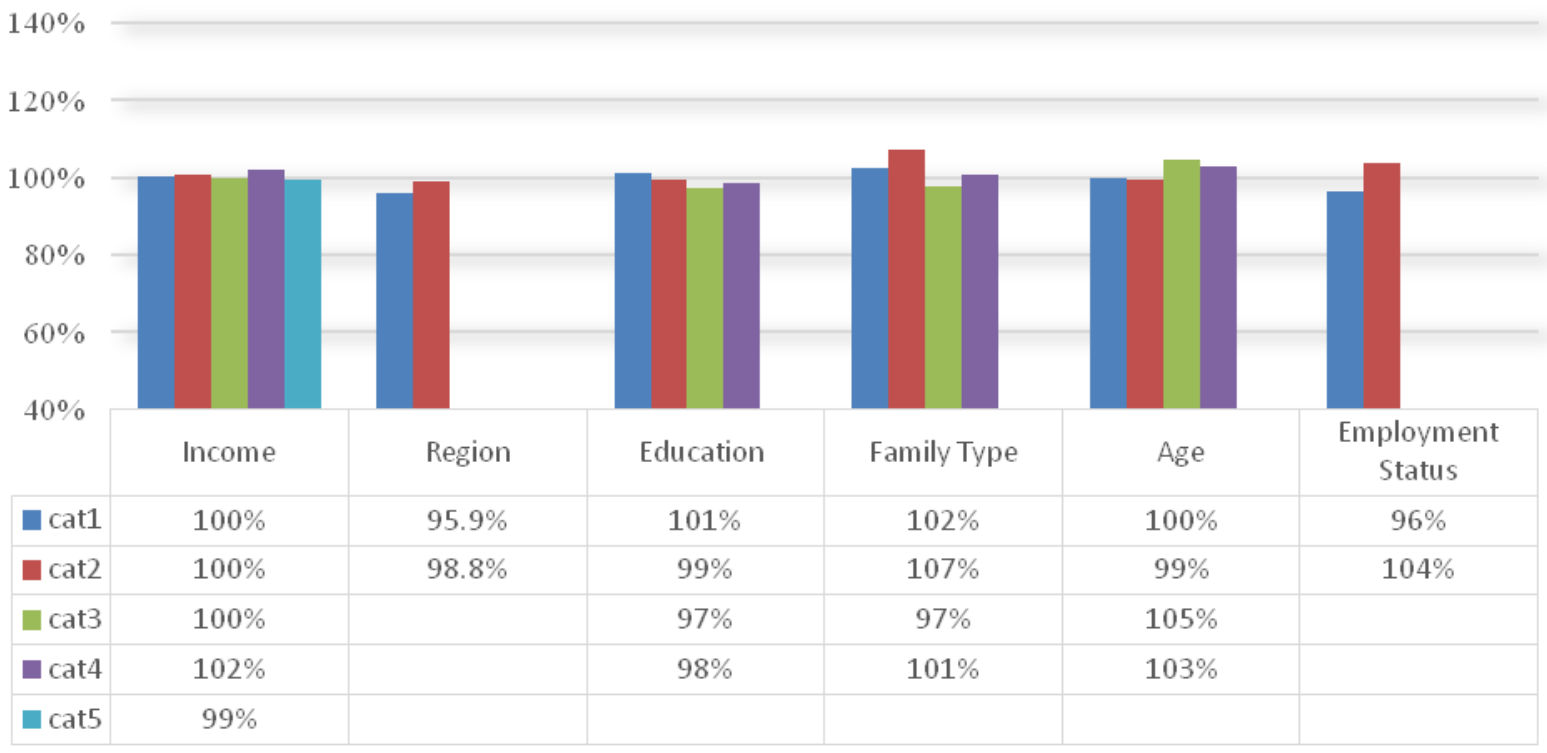

Figure 6: Ratio of Median Household Expenditure by Category (Match/HBS), 2005

Ratio of Median Household Expenditure by Category (Match/HBS 2005)

$140 \%$

\begin{tabular}{|c|c|c|c|c|c|}
\hline $120 \%$ & & & & & \\
\hline
\end{tabular}


Figure 7: Ratio of Mean Household Expenditure by Category (Match/HBS), 2008 Ratio of Mean Household Expenditure by Category (Match/HBS 2008)

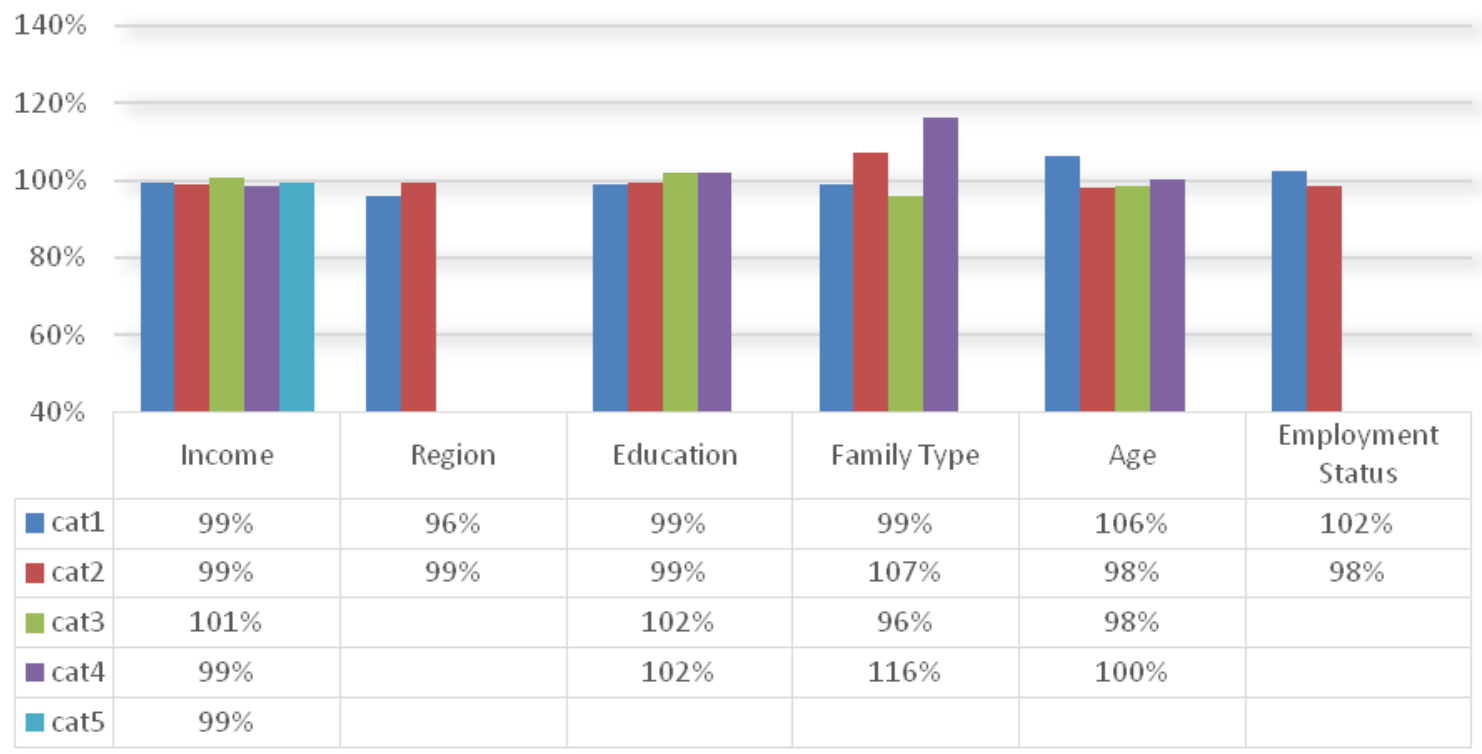

Figure 8: Ratio of Median Household Expenditure by Category (Match/HBS), 2008 Ratio of Median Household Expenditure by Category (Match/HBS 2008)

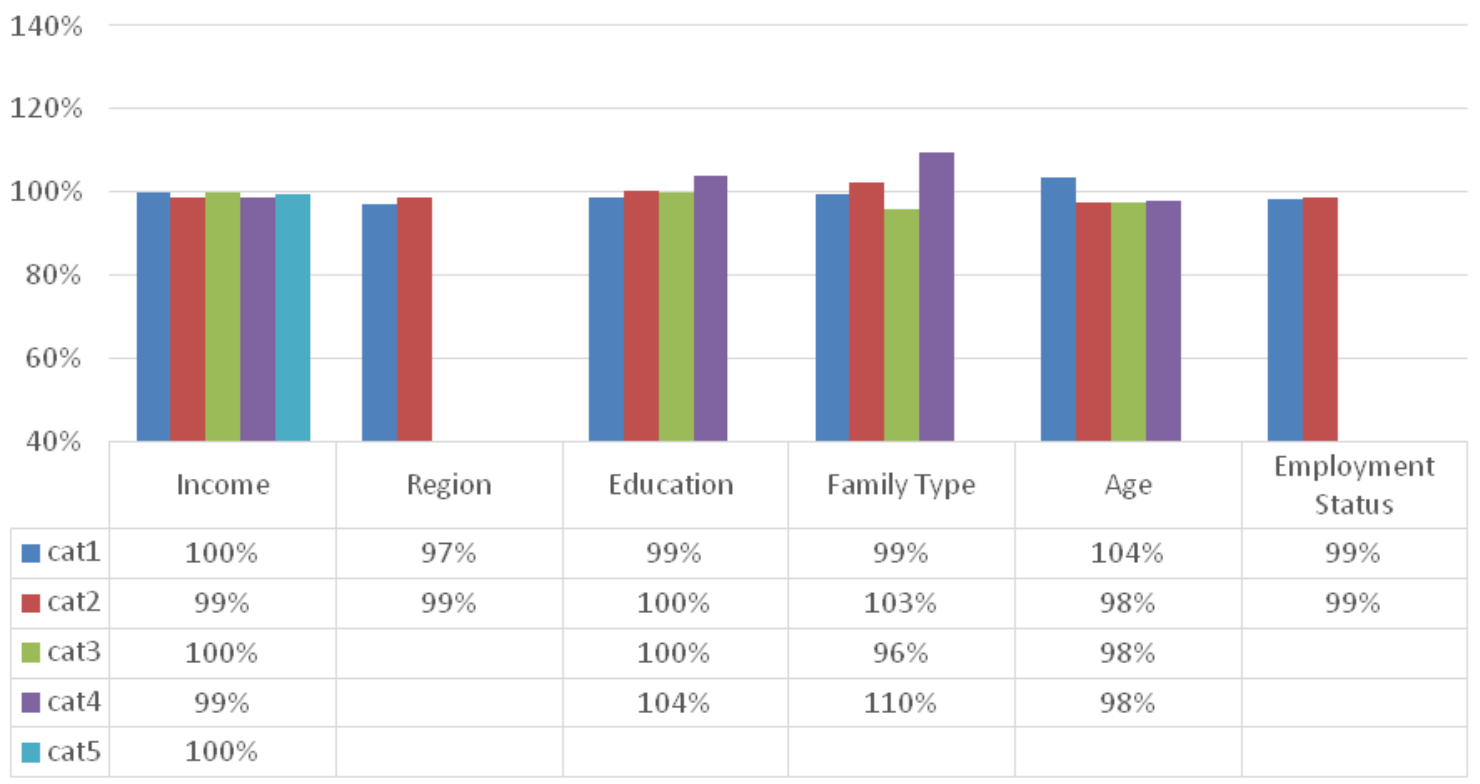


Figure 9: Ratio of Mean Household Expenditure by Category (Match/HBS), 2009 Ratio of Mean Household Expenditure by Category (Match/HBS 2009)

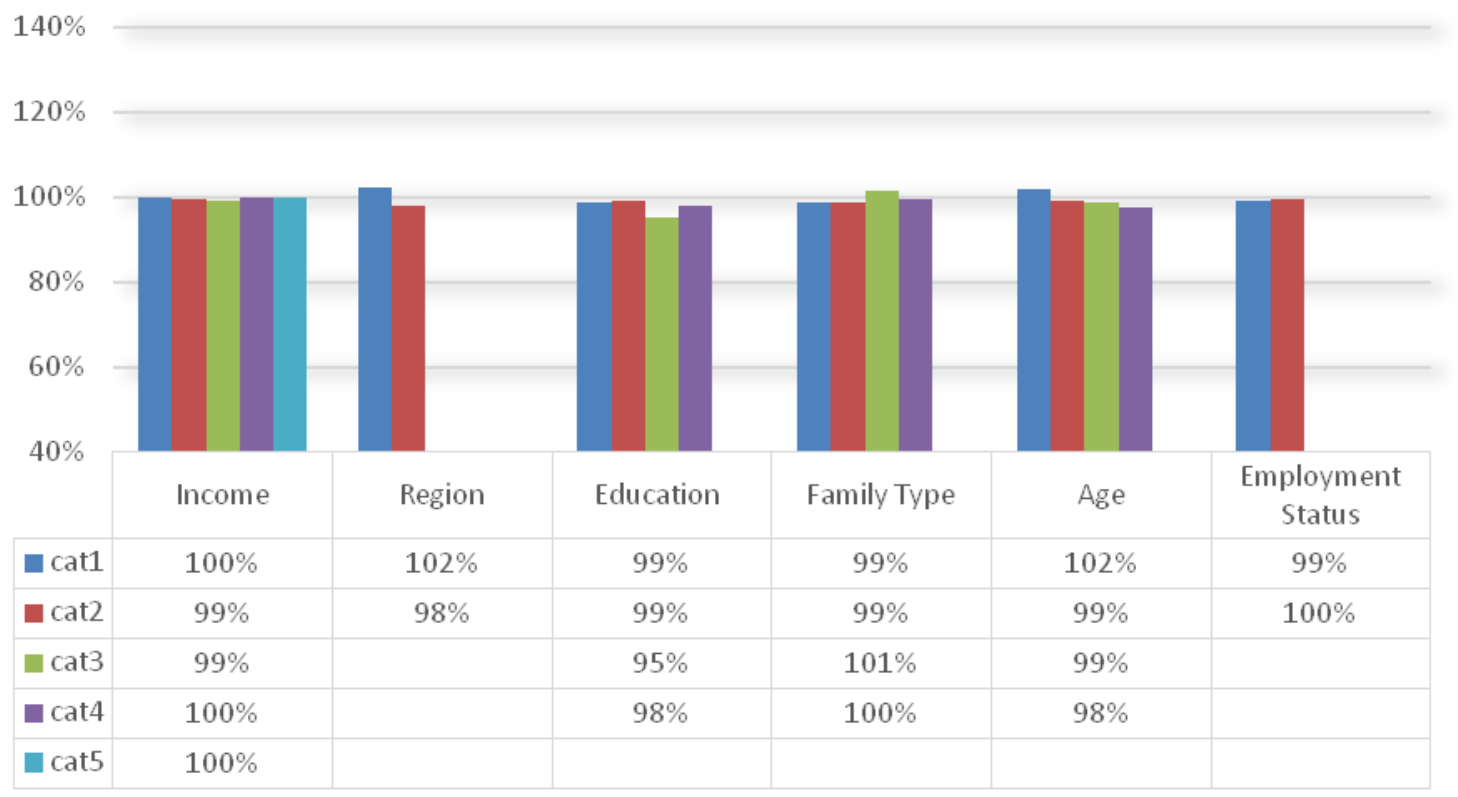

Figure 10: Ratio of Median Household Expenditure by Category (Match/HBS), 2009 Ratio of Median Household Expenditure by Category (Match/HBS 2009)

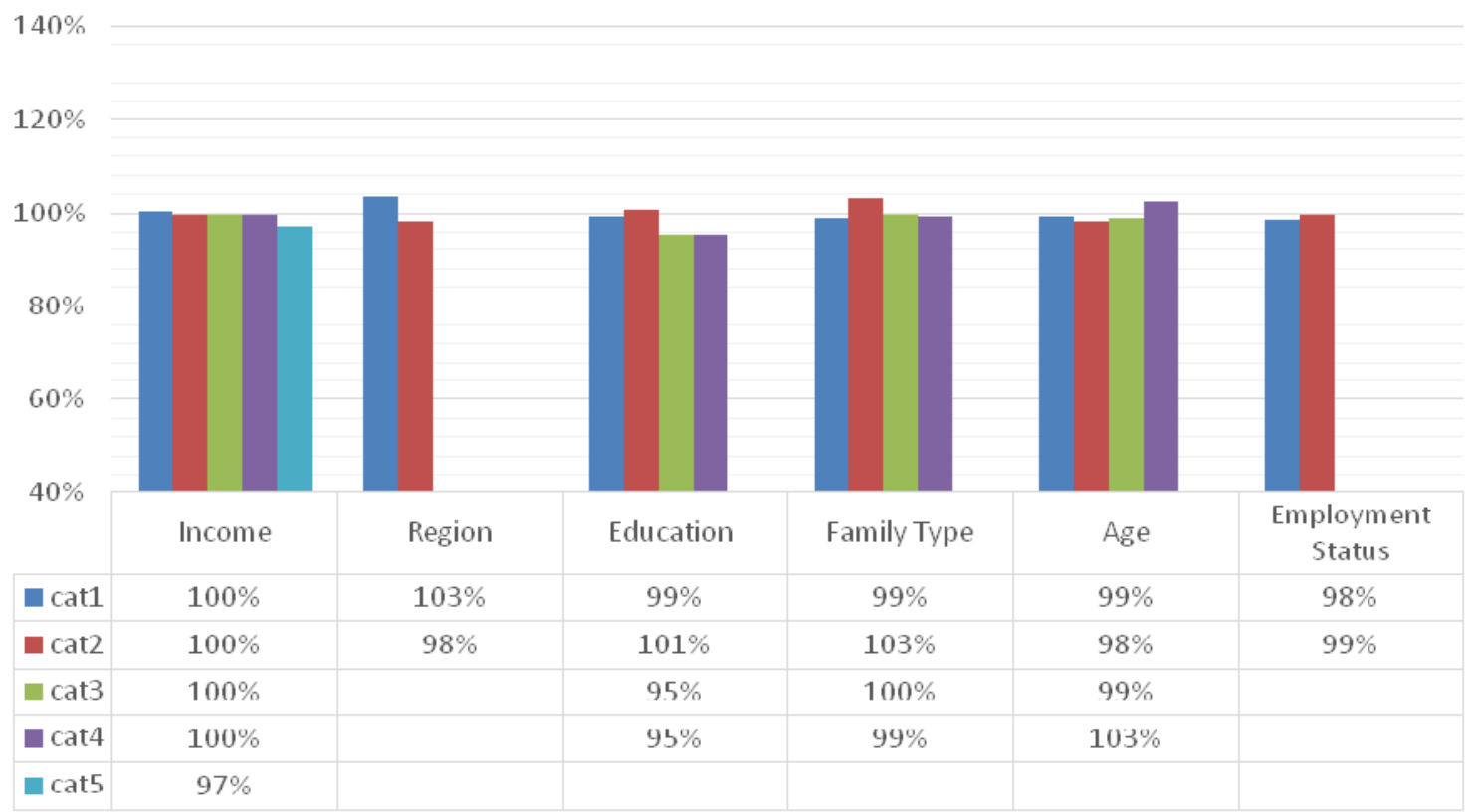


Figure 11: Ratio of Mean Household Expenditure by Category (Match/HBS), 2012

Ratio of Mean Household Expenditure by Category

(Match/HBS 2012)

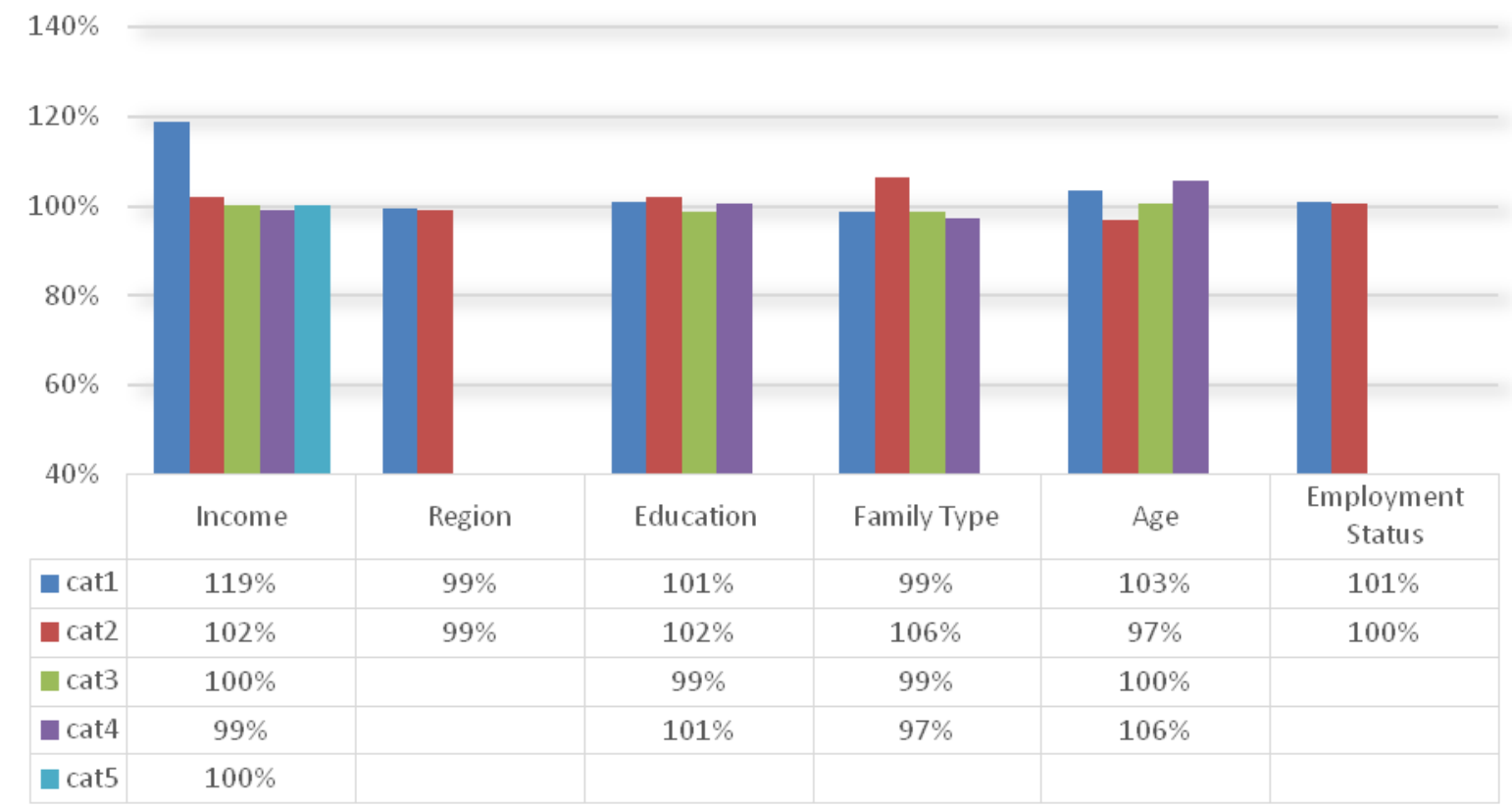

Figure 12: Ratio of Median Household Expenditure by Category (Match/HBS), 2012

Ratio of Median Household Expenditure by Category (Match/HBS 2012)

$140 \%$

\begin{tabular}{|c|c|c|c|c|c|c|}
\hline \multicolumn{7}{|l|}{$100 \%$} \\
\hline $80 \%$ & & & & & & \\
\hline $60 \%$ & & & & & & \\
\hline $40 \%$ & Income & Region & Education & Family Type & Age & $\begin{array}{c}\text { Employment } \\
\text { Status }\end{array}$ \\
\hline at1 & $107 \%$ & $98 \%$ & $101 \%$ & $98 \%$ & $103 \%$ & $100 \%$ \\
\hline a cat2 & $101 \%$ & $98 \%$ & $100 \%$ & $104 \%$ & $96 \%$ & $99 \%$ \\
\hline cat3 & $100 \%$ & & $97 \%$ & $99 \%$ & $99 \%$ & \\
\hline cat4 & $98 \%$ & & $100 \%$ & $98 \%$ & $106 \%$ & \\
\hline cat5 & $100 \%$ & & & & & \\
\hline
\end{tabular}


Figure 13: Mean and Median of Household Expenditure by Region, Income, and Age Categories (Match/HBS), 2005

Mean and Median of Household Expenditure by region, income and age categories(Match/HBS), 2005

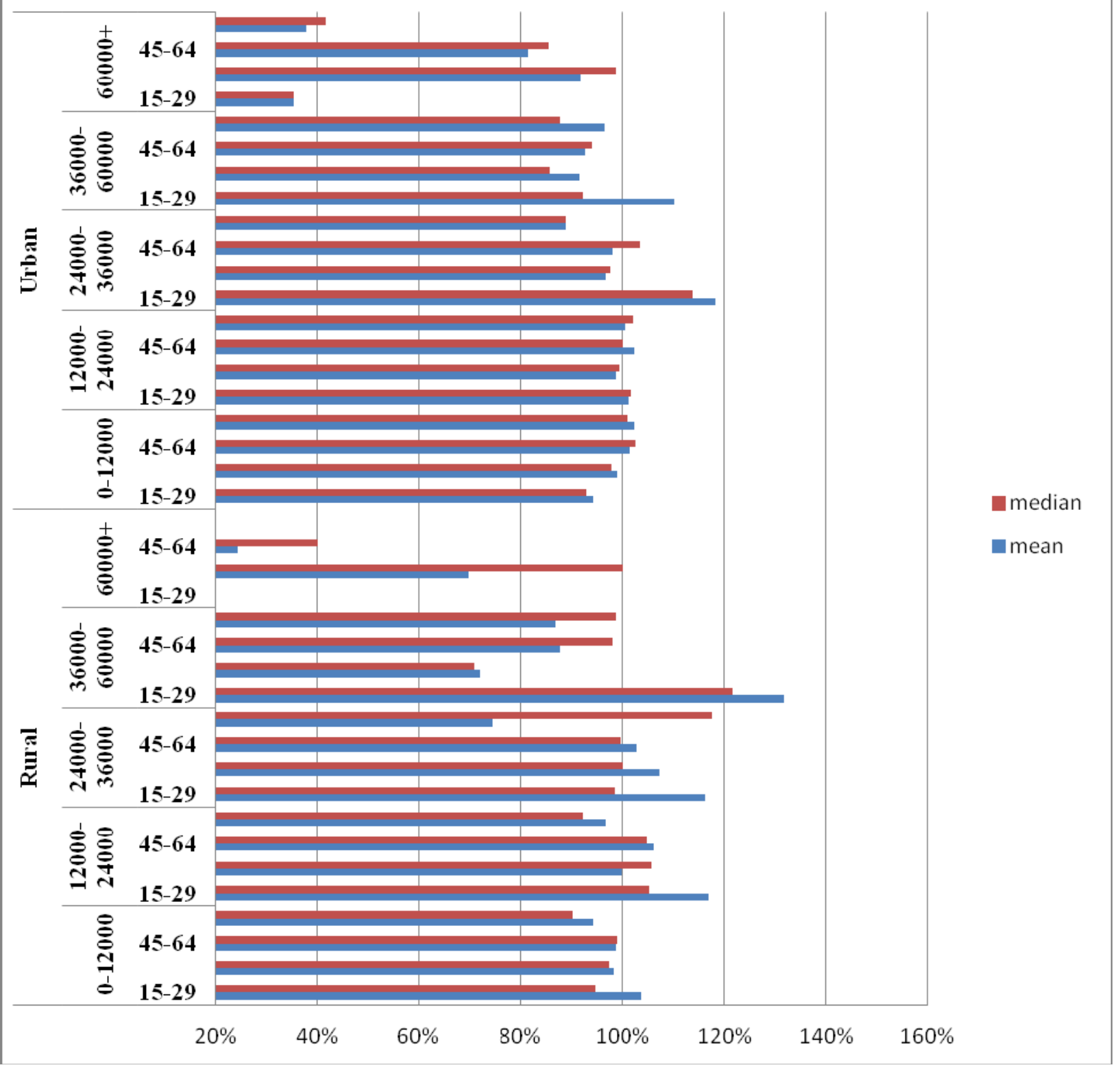


Figure 14: Mean and Median of Household Expenditure by Region, Income, and Age Categories (Match/HBS), 2012

\section{Mean and Median of Household Expenditure by region, income and age categories (Match/HBS), 2012}

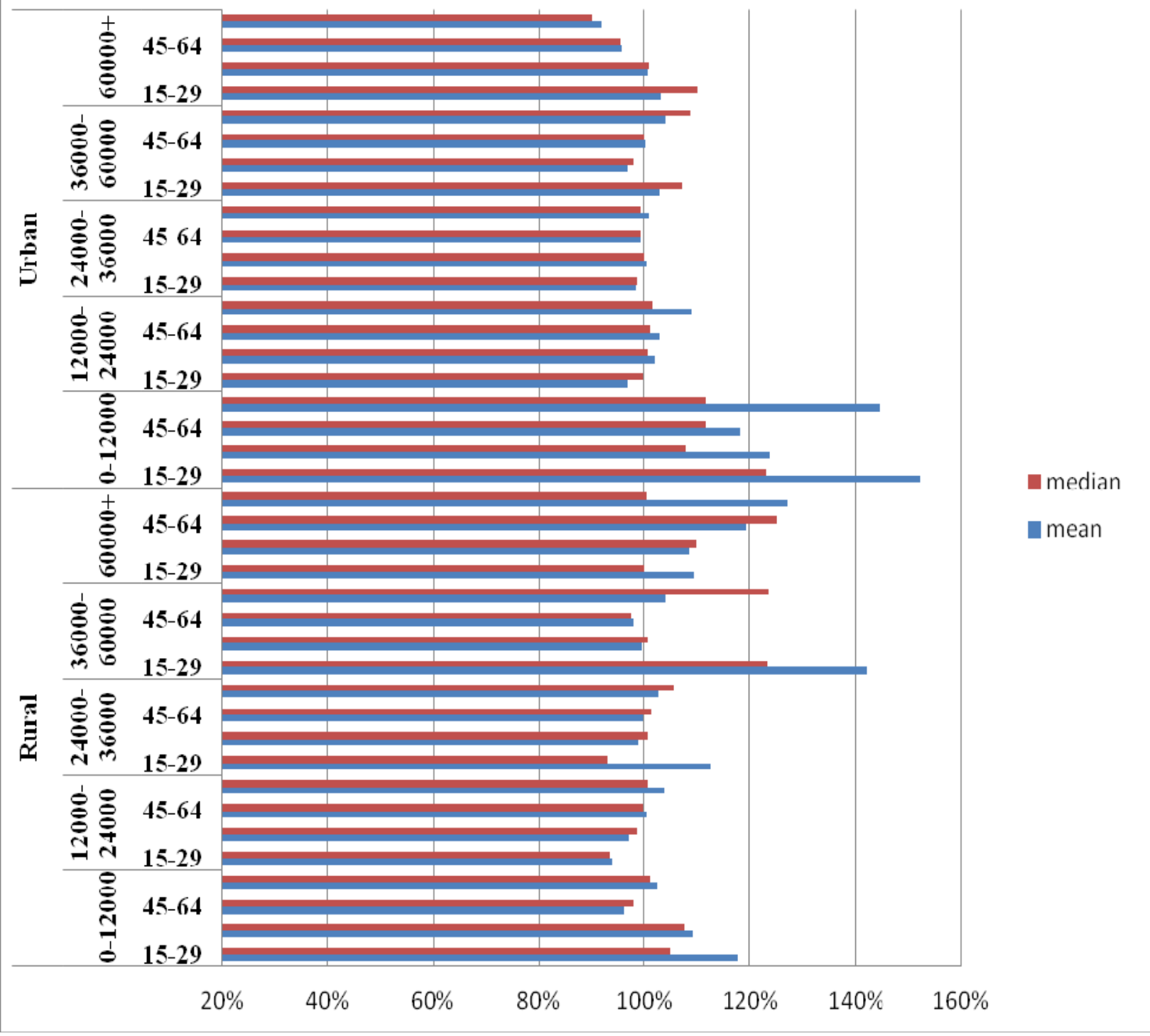

